\title{
Development of an ASPEN PLUS Physical Property Database for Biofuels Components
}

Robert J. Wooley

Victoria Putsche

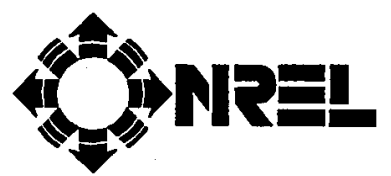

National Renewable Energy Laboratory 1617 Cole Boulevard Golden, Colorado 80401-3393

A national laboratory of the U.S. Department of Energy Managed by Midwest Research Institute for the U.S. Department of Energy under Contract No. DE-AC36-83CH10093

Prepared under Task No. BF521004 


\section{NOTICE}

This report was prepared as an account of work sponsored by an agency of the United States govemment. Neither the United States govemment nor any agency thereof, nor any of their employees, makes any warranty, express or implied, or assumes any legal liability or responsibility for the accuracy, completeness, or usefulness of any information, apparatus, product, or process disclosed, or represents that its use would not infringe privately owned rights. Reference herein to any specific commercial product, process, or service by trade name, trademark, manufacturer, or otherwise does not necessarily constitute or imply its endorsement, recommendation, or favoring by the United States government or any agency thereof. The views and opinions of authors expressed herein do not necessarily state or reflect those of the United States govemment or any agency thereof.

Available to DOE and DOE contractors from:

Office of Scientific and Technical Information (OSTI)

P.O. Box 62

Oak Ridge, TN 37831

Prices available by calling (423) $576-8401$

Available to the public from:

National Technical Information Service (NTIS)

U.S. Department of Commerce

5285 Port Royal Road

Springfield, VA 22161

(703) $487-4650$ 


\section{Table of Contents}

Page

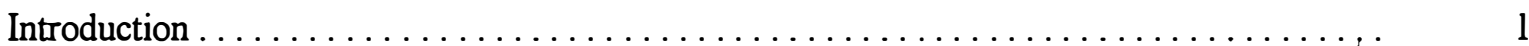

Aspen's Approach to Physical Properties

Minimum Physical Properties Required by Aspen

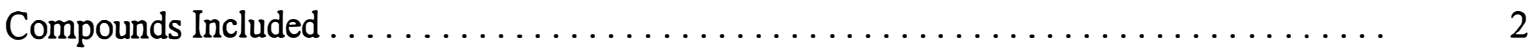

Combustion Stoichiometry $\ldots \ldots \ldots \ldots \ldots \ldots \ldots \ldots \ldots \ldots \ldots \ldots \ldots \ldots \ldots \ldots \ldots \ldots \ldots \ldots \ldots \ldots$

Description of Properties Included in the Database $\ldots \ldots \ldots \ldots \ldots \ldots \ldots \ldots \ldots \ldots$

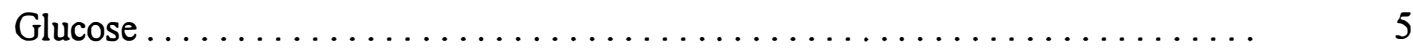

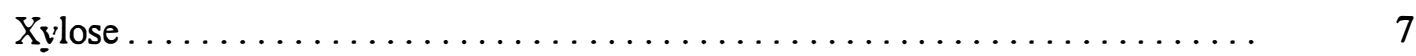

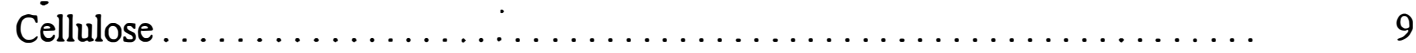

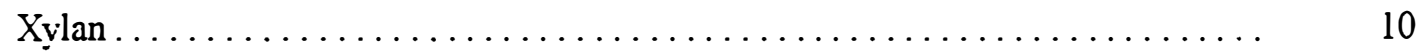

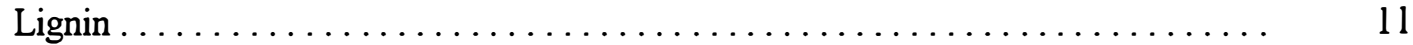

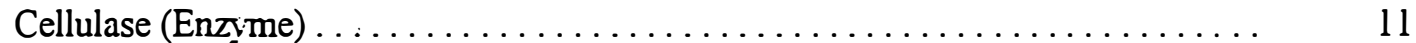

Biomass (Cell Mass) . . . . . . . . . . . . . . . . . . . . . . . . . . . . . . . $\quad 12$

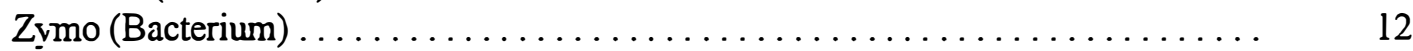

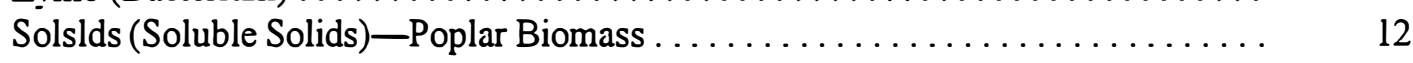

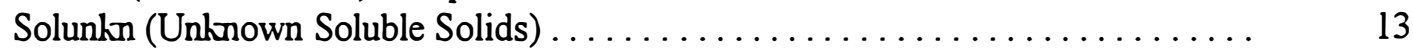

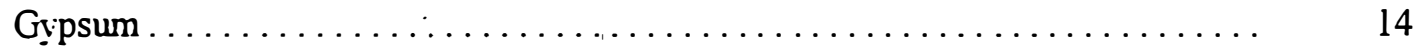

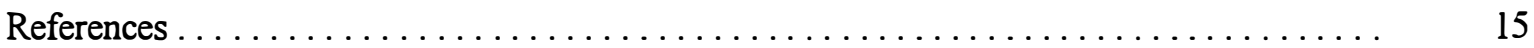

Appendix A: $\quad$ ASPEN PLUS DFMS (Data File Management System) Input File . . . . . $\quad 17$

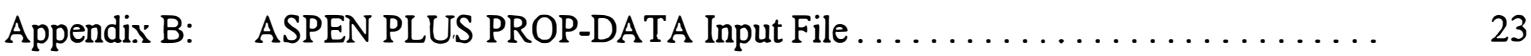

Appendix C: Quality of Properties in INHSPCD Databank for ASPEN PLUS . . . . . . . 28

Appendix D: Values in ASPEN PUS INHSPCD (NREL Biofuels) Databank . . . . . . . 29

Appendix E: $\quad$ Data Values in ASPEN PLUS NREL Biofuels INHSPCD Databank . . . . . 30

Appendix F: $\quad$ ASPEN PLUS Physical Property Route Modifications to Enable the DIPPR Liquid Heat Capacity Correlation 


\section{Introduction}

Physical property data for many of the key components used in the simulation for the ethanol from lignocellulose process are not available in the standard ASPEN PLUS property databases. Indeed, many of the properties necessary to successfully simulate this process are not available anywhere. In addition, inputting the available properties into each simulation is awkward and tedious, and mistakes can be easily introduced when a long list of physical property equation parameters is entered. Therefore, we must evaluate the literature, estimate properties where necessary, and determine a set of consistent physical properties for all components of interest. The components must then be entered into an in-house NREL ASPEN PLUS database so they can be called on without being retyped into each specific simulation.

The first phase of this work is complete. A complete set of properties for the currently identifiable important compounds in the ethanol process is attached. With this as the starting base we can continue to search for and evaluate new properties or have properties measured in the laboratory and update the central database.

\section{Aspen's Approach to Physical Properties}

The Aspen simulator handles three classes of compounds:

1. Those (such as ethanol) that are involved in vapor liquid equilibrium;

2. Those (such as $\mathrm{CaSO}_{4}$ ) that are solids only and are identifiable: and

3. Solids (such as coal) that are identifiable by attribute only.

This database will deal with the first two types only.

For compounds involved in vapor liquid equilibrium, the simulator must have a complete set of properties to allow it to do flash calculations, even though the compound may be a very high boiler and will stay in the liquid phase exclusively: Also, materials such as glucose and xylose, which are commonly solids but will be used exclusively in aqueous solution in the process, will be treated as liquids.

The second class, which includes cellulose and gypsum, is assumed to comprise conventional solids whose properties requirements are very minimal. A conventional solid can (unlike nonconventional solids that must be described by attributes) be defined by a chemical formula.

\section{Minimum Physical Properties Required by Aspen}

The minimum phisical properties required by Aspen depend on the calculation routes selected for fundamental properties such as liquid, vapor, and solid enthalpy and density. In general, because of the need to distill ethanol and to handle dissolved gases, the standard NRTL (non-random two liquid or Renon) route is used. This route, which includes the NRTL liquid activity coefficient model, Henry's law for the dissolved gases, and RKS (Redlich-Kwong-Soave) equation of state for the vapor phase, is used to calculate properties for components in the liquid and vapor phases. It also uses the Ideal Gas (IG) at $25^{\circ} \mathrm{C}$ as the standard reference state, thus requiring the heat of formation at these conditions (Table 1). 
Table 1. Required Properties

\begin{tabular}{ll}
\hline Liquids/Gases & Conventional Solids \\
\hline Critical Temperature & Heat of Formation \\
Critical Pressure & Heat Capacity \\
IG Heat of Formation @ 298.15K & Density \\
Vapor Pressure & \\
IG Heat Capacity & \\
Heat of Vaporization & \\
Liquid Density & \\
\hline
\end{tabular}

Many components used here will not be involved in vapor liquid equilibrium, as they stay in the liquid phase under the operating conditions experienced during the ethanol process. However, because of the above requirements, vapor properties will be needed. These will be estimated, but as long as the vapor pressure is low enough, the compounds will never actually show up in the vapor phase, and the liquid properties of interest will be calculated correctly.

Table 2 lists the compounds included in the current database, along with their primary state and formula. Isomers were not considered independently; because most of the desired properties are being estimated, there will not be a significant difference between isomers. This will not preclude the use of isomers in simulations, but there will be no physical difference between isomers in the simulations. For example, all five-carbon sugars should use the properties of xylose, and six-carbon sugars those of glucose. The chemical formulas used for compounds such as biomass and cellulase were obtained from Radian Corporation ${ }^{1}$ and Putsche, ${ }^{2}$ respectively: Solslds are essentially everything combustible that is not one of the identifiable cellulose, lignin, or hemicellulose materials in biomass. The formula for solslds corresponds to the difference between the ultimate analysis of the biomass and the number of identifiable compounds. The heating value of solslds is the difference between that of the original biomass and the sum of the identifiable components. The solslds listed here correspond to poplar biomass and would differ for other sources of biomass. The solunkn is a compound that elutes at a similar position to xylitol, but is unknown. It was given a reduced formula of xylose for material balances only. 
Table 2. Compounds Included in the ASPEN PLUS Database (INHSPCD)

\begin{tabular}{lllll}
\hline $\begin{array}{l}\text { Compound } \\
\text { Name }\end{array}$ & Formula & $\begin{array}{l}\text { Database } \\
\text { Name }\end{array}$ & Database Alias & Normal State \\
\hline Glucose & $\mathrm{C}_{6} \mathrm{H}_{12} \mathrm{O}_{6}$ & GLUCOSE & $\mathrm{C} 6 \mathrm{H} 12 \mathrm{O} 6$ & Liquid (aqueous). \\
Xylose & $\mathrm{C}_{5} \mathrm{H}_{10} \mathrm{O}_{5}$ & XYLOSE & $\mathrm{C} 5 \mathrm{H} 10 \mathrm{O} 5$ & Liquid (aqueous) \\
Cellulose & $\mathrm{C}_{6} \mathrm{H}_{10} \mathrm{O}_{5}{ }^{*}$ & CELLULOS & $\mathrm{C} 6 \mathrm{H} 10 \mathrm{O} 5$ & Solid \\
Xylan & $\mathrm{C}_{5} \mathrm{H}_{8} \mathrm{O}_{4^{*}}$ & XYLAN & $\mathrm{C} 5 \mathrm{H} 8 \mathrm{O} 4$ & Solid \\
Lignin & $\mathrm{C}_{7.3} \mathrm{H}_{13.9} \mathrm{O}_{1.3}$ & LIGNIN & $\mathrm{CXHXOX}$ & Solid \\
$\begin{array}{l}\text { Biomass } \\
\text { (cell mass) }\end{array}$ & $\mathrm{CH}_{1.64} \mathrm{~N}_{0.23} \mathrm{O}_{0.39} \mathrm{~S}_{0.0035}$ & BIOMASS & CHXNXOXSX-1 & Solid \\
Cellulase & $\mathrm{CH}_{1.57} \mathrm{~N}_{0.29} \mathrm{O}_{0.31} \mathrm{~S}_{0.007}$ & CELLULAS & CHXNXOXSX-2 & Solid \\
Zymo & $\mathrm{CH}_{1.8} \mathrm{O}_{0.5} \mathrm{~N}_{0.2}$ & ZYMO & CHXOXNX & Solid \\
Solslds & $\mathrm{CH}_{1.48} \mathrm{O}_{0.019} \mathrm{~S}_{0.0013}$ & SOLSLDS & CHXOXSX & Liquid (aqueous) \\
Solunkn & $\mathrm{C}_{0.5} \mathrm{HO}_{0.5}$ & SOLUNKN & CXHOX & Liquid (aqueous) \\
Gypsum & $\mathrm{CaSO}_{4} \cdot 2 \mathrm{H}_{2} \mathrm{O}$ & GYPSUM & CaSO4-2H2O & Solid \\
\hline
\end{tabular}

* For the polymeric compounds a formula corresponding to a single repeat unit was used.

\section{Combustion Stoichiometry}

In all cases the heat of combustion was found in the literature or estimated and used to calculate the heat of formation. To calculate the heat of formation necessary for other heat of reaction calculations, we must know the compound's molecular formula (and consequently its combustion stoichiometry). Given the above molecular formulas, the combustion stoichiometry used for each compound is given below.

Glucose .

$\mathrm{C}_{6} \mathrm{H}_{12} \mathrm{O}_{6}+6 \mathrm{O}_{2} \rightarrow 6 \mathrm{H}_{2} \mathrm{O}+6 \mathrm{CO}_{2} \mathrm{M}$

Xylose

$\mathrm{C}_{5} \mathrm{H}_{10} \mathrm{O}_{5}+5 \mathrm{O}_{2} \rightarrow 5 \mathrm{H}_{2} \mathrm{O}+5 \mathrm{CO}_{2} \mathrm{M}$

Cellulose

$\mathrm{C}_{6} \mathrm{H}_{10} \mathrm{O}_{5}+6 \mathrm{O}_{2} \rightarrow 5 \mathrm{H}_{2} \mathrm{O}+6 \mathrm{CO}_{2}$

Xvilan

$\mathrm{C}_{5} \mathrm{H}_{8} \mathrm{O}_{4}+5 \mathrm{O}_{2}-4 \mathrm{H}_{2} \mathrm{O}+5 \mathrm{CO}_{2} \mathrm{M}$ 
Lignin

$\mathrm{C}_{7.3} \mathrm{H}_{13.9} \mathrm{O}_{1.3}+10.125 \mathrm{O}_{2} \rightarrow 6.95 \mathrm{H}_{2} \mathrm{O}+7.3 \mathrm{CO}_{2}$

Biomass

$\mathrm{CH}_{1.64} \mathrm{~N}_{0.23} \mathrm{O}_{0.39} \mathrm{~S}_{0.0035}+1.2185 \mathrm{O}_{2} \rightarrow 0.82 \mathrm{H}_{2} \mathrm{O}+\mathrm{CO}_{2}+0.0035 \mathrm{SO}_{2}+0.115 \mathrm{~N}_{2}$

Cellulase

$\mathrm{CH}_{1.57} \mathrm{~N}_{0.29} \mathrm{O}_{0.31} \mathrm{~S}_{0.007}+1.2445 \mathrm{O}_{2}-0.785 \mathrm{H}_{2} \mathrm{O}+\mathrm{CO}_{2}+0.007 \mathrm{SO}_{2}+0.145 \mathrm{~N}_{2}$

Zymo

$\mathrm{CH}_{1.8} \mathrm{O}_{0.5} \mathrm{~N}_{0.2}+1.2 \mathrm{O}_{2} \rightarrow 0.9 \mathrm{H}_{2} \mathrm{O}+\mathrm{CO}_{2}+0.1 \mathrm{~N}_{2}$

Solslds

$\mathrm{CH}_{1.48} \mathrm{O}_{0.19} \mathrm{~S}_{0.0013}+1.2763 \mathrm{O}_{2}-0.74 \mathrm{H}_{2} \mathrm{O}+\mathrm{CO}_{2}+0.0013 \mathrm{SO}_{2}$

Solunkn

$\mathrm{C}_{0.5} \mathrm{HO}_{0.5}+0.5 \mathrm{O}_{2}-0.5 \mathrm{H}_{2} \mathrm{O}+0.5 \mathrm{CO}_{2}$

In addition to the reaction stoichiometry, the heat of formation of the combustion products is required to calculate heat of formation from heat of combustion. The values used here are:

Compound

$\mathrm{H}_{2} \mathrm{O}$ (liquid)

Heat of Formation @ $298 \mathrm{~K}$

$\mathrm{CO}_{2}$ (IG)

$\mathrm{SO}_{2}$ (IG)

$-68.7979 \mathrm{kcal} / \mathrm{mole}$

$-94.052 \mathrm{kcal} / \mathrm{mole}$

$-70.899 \mathrm{kcal} / \mathrm{mole}$

$$
\begin{aligned}
& -2.88043 \times 10^{8} \mathrm{~J} / \text { Kmole } \\
& -3.93776 \times 10^{8} \mathrm{~J} / \text { Kmole } \\
& -2.9684 \times 10^{8} \mathrm{~J} / \mathrm{Kmole}
\end{aligned}
$$

These values were taken from the ASPEN PLUS Pure Component databank to be consistent with the calculations to be performed in ASPEN PLUS.

\section{Description of Properties Included in the Database}

Following is a description of the source methods and estimation used to develop properties for all compounds listed above. These properties are in the new ASPEN PLUS INHSPCD (Inhouse Pure Component Database) and are enclosed as inputs to the DFMS (Data File Management System) (Appendix A) and as ASPEN PLUS Input language PROP-DATA statements (Appendix B). (All properties are in SI units.) A summary of sources of all properties appears in Appendix $\mathrm{C}$ and a summary of the properties in the in-house database appears in Appendix D.

The ASPEN PLUS DFMS allows a source code to be entered for each property. Rather than using an actual reference number, this is used for a quality code. The following quality codes have been assigned to each data set. In general, data with a higher confidence level correspond to higher numbers. 


\begin{tabular}{|c|c|}
\hline Code & Data Quality Codes Used in the Biofuels INHSPCD \\
\hline $\begin{array}{l}\text { Code } \\
9\end{array}$ & $\begin{array}{l}\text { Code Description } \\
\text { Literature data }\end{array}$ \\
\hline 8 & Regressed to literature data \\
\hline 7 & Calculated directly (e.g. MW) \\
\hline 6 & Calculated from other literature data (e.g. \\
\hline 5 & Estimated from the commercial property estimation package PREDICT \\
\hline 4 & Estimated, but not from PREDICT \\
\hline 3 & Copied literature data from a similar compound on a mass basis \\
\hline 2 & Copied literature data from a similar compound on a mole basis \\
\hline 1 & Copied data of various origin from a similar compound \\
\hline 0 & Unknown origin \\
\hline
\end{tabular}

\section{Glucose}

Glucose, although a generally considered a solid at the temperatures involved in the ethanol process, is exclusively in aqueous solution. It will therefore be modeled as a liquid, although it will never exist as a pure liquid in the process. The properties listed here are NOT intended for use with pure glucose, or even with concentrated solutions. The vapor pressure is low enough (the normal boiling point has been estimated to be higher than 800 $\mathrm{K})$ that the glucose will never be flashed into the vapor stream.

\section{Point Properties}

\section{Properties (Quality Code) Methodology}

Molecular Weight

Critical Temperature

Critical Pressure

Critical Volume

Acentric Factor

IG Heat of Formation

IG Free Ergy. of Form. (9)

(a) $298.15 \mathrm{~K}$
Calculated directly.

Estimated using the Joback ${ }^{3}$ group contribution method in PREDICT. Estimated using the Joback $^{-3}$ group contribution method in PREDICT. Estimated using the Joback $^{-3}$ group contribution method in PREDICT. Estimated using the Pitzer $^{4}$ vapor pressure correlation and the estimated normal boiling point in PREDICT.

Literature ${ }^{5}$ value was $-1.2735 \times 10^{9} \mathrm{~J} / \mathrm{Kmole}$. Using this value, and the $\Delta \mathrm{H}_{\mathrm{F}}$ (liquid) calculated from the literature value for higher $\Delta \mathrm{H}_{\mathrm{C}}(673$ $\mathrm{kcal} / \mathrm{mole}^{4}$ ), the heat of vaporization (difference between $\Delta \mathrm{H}_{\mathrm{F}}[\mathrm{IG}]$ and $\Delta \mathrm{H}_{\mathrm{F}}$ [liquid or solid, $\Delta \mathrm{H}_{\text {SOLN }}$ is small]) would have to be less than zero. Therefore, the heat of vaporization was set at a very small value (see below) and the $\Delta \mathrm{H}_{\mathrm{F}}(\mathrm{IG})$ from the literature adjusted slightly to give the value of $-1.2569 \times 10^{9} \mathrm{~J} / \mathrm{Kmole}$ used in the database. See Table 3 for a comparison of the original $\Delta \mathrm{H}_{\mathrm{C}}$ and those back calculated from Aspen.

Literature $^{5}$ 


\begin{tabular}{|c|c|c|c|c|c|c|c|c|c|}
\hline & & \multicolumn{4}{|c|}{ Higher Heating Values Calculated from ASPEN } & \multicolumn{4}{|c|}{ |Higher Heating Values Calculated from Literature } \\
\hline & MW & $\mathrm{J} / \mathrm{Kmol}$ & Kcal/gmole & |BTU/lbmole & BTU/lb & J/Kmol & Kcal/gmole & |BTU/lbmole & |BTU/I \\
\hline Glucose & 180.16 & $2.81776 \mathrm{E}+09$ & 673.01 & 1212242 & 6728.70 & & 673 & & \\
\hline Xylose & 150.132 & $2.35178 E+09$ & 561.71 & 1011771 & 6739.21 & & 561.5 & & \\
\hline Cellulose & 162.1436 & $2.81312 E+09$ & 671.90 & 1210246 & 7464.04 & $2.81311 E+09$ & $671: 8987$ & 1210240 & 7464 \\
\hline Xylan & 132.117 & $2.34787 E+09$ & 560.78 & 1010089 & 7645.41 & & 560.6 & & \\
\hline Lignin & 122.493 & $3.26548 E+09$ & 779.95 & 1404858 & 11468.88 & $3.26751 \mathrm{E}+09$ & 780.4304 & 1405730 & 11476 \\
\hline Biomass & 23.238 & $5.31676 E+08$ & 126.99 & 228734.9 & 9843.14 & $5.32425 E+08$ & 127.1674 & 229057 & 9857 \\
\hline |Zymo & 24.6264 & $5.20125 E+08$ & 124.23 & 223765.5 & 9086.41 & & 124.8 & & \\
\hline Cellulase & 22.8398 & $5.44906 \mathrm{E}+08$ & 130.15 & 234426.7 & 10263.95 & $5.45015 E+08$ & 130.1745 & 234473.4 & 10266 \\
\hline Solslds & 16.5844 & $5.53575 E+08$ & 132.22 & 238156.2 & 14360.25 & & 132.7 & & \\
\hline Solunkn & 15.0134 & $2.16411 \mathrm{E}+08$ & 51.69 & 93103.23 & 6201.34 & & 52 & & \\
\hline $\mathrm{EtOH}$ & 46.0691 & $1.36661 \mathrm{E}+09$ & 326.41 & 587935.9 & 12762.04 & & 327.6 & & \\
\hline \multicolumn{6}{|c|}{ Heat of Reaction to Form Ethanol Calculated from ASPEN } & \multicolumn{4}{|c|}{ Heat of Rxn to Form EtOH from Literature } \\
\hline Glucose & 180.16 & $8.45388 \mathrm{E}+07$ & 20.19 & 36369.85 & 201.88 & & 19.6 & & \\
\hline Xylose & 150.132 & $7.41032 E+07$ & $17.70 \mid$ & 31880.3 & 212.35 & & $\mid \overline{15.5 \mid}$ & & \\
\hline
\end{tabular}

\section{Temperature-Correlated Properties}

\section{Properties}

Vapor Pressure

IG Heat Capacity

Heat of Vaporization

Liquid Density

Liquid Heat Capacity

)

(8)




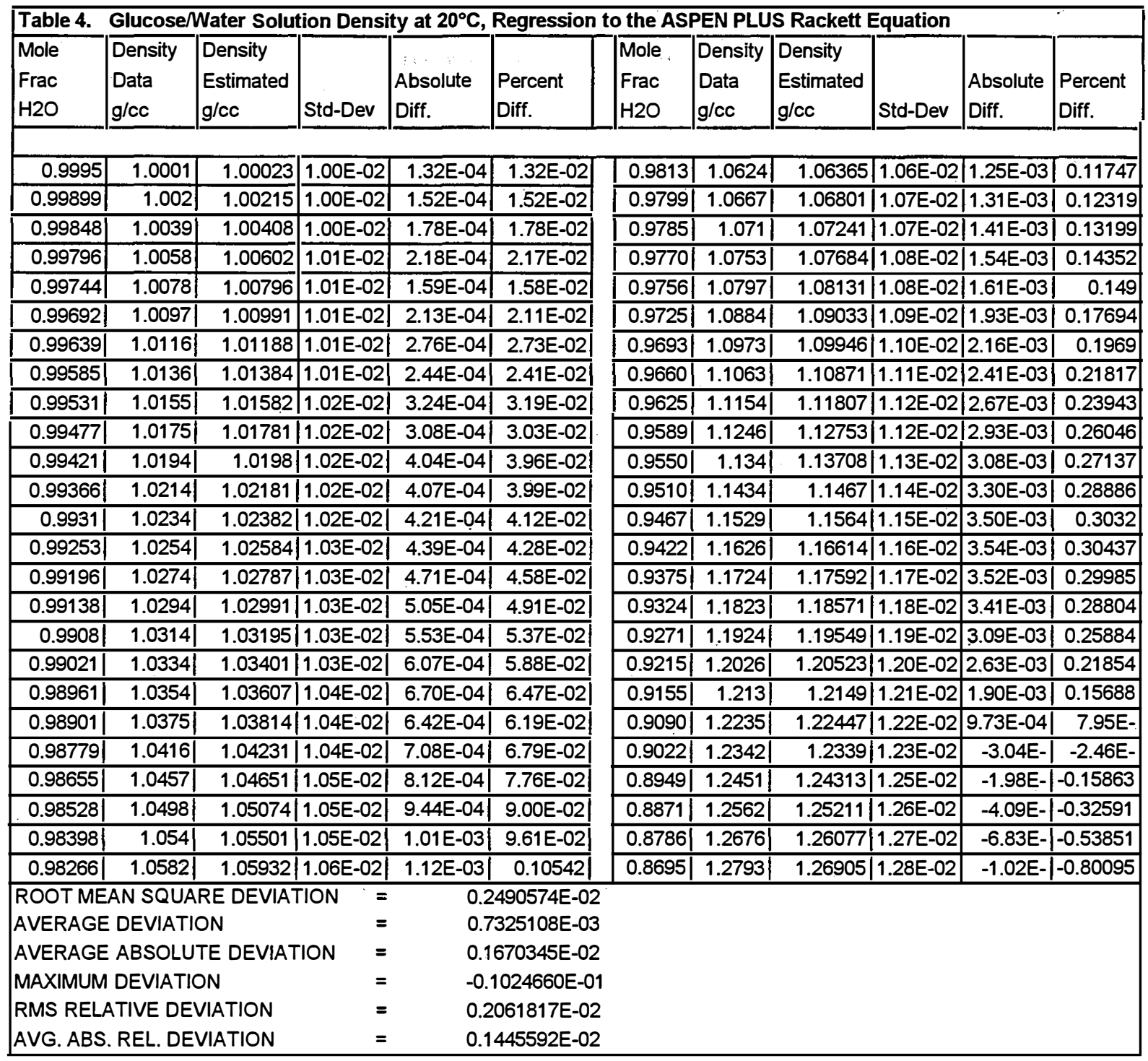

\section{Xylose}

Xylose, like glucose, is a generally considered a solid at the temperatures involved in the ethanol process, but is exclusively in aqueous solution. Therefore, it will be modeled as a liquid, although it will never exist as a pure liquid in the process. The properties listed here are NOT intended for use with pure xylose or even with concentrated solutions. The vapor pressure is low enough (the normal boiling point has been estimated to be higher than $800 \mathrm{~K}$ ) that the xylose will never be flashed into the vapor stream. 


\section{Point Properties}
Properties
(Quality Code) Methodology
Molecular Weight
Critical Temperature
Critical Pressure
Critical Volume
Acentric Factor
IG Heat of Formation
(a) $298.15 \mathrm{~K}$
Calculated directly.
Estimated using the Joback ${ }^{3}$ group contribution method in PREDICT.
Estimated using the Joback ${ }^{3}$ group contribution method in PREDICT.
Estimated using the Joback ${ }^{3}$ group contribution method in PREDICT.
Estimated using the Pitzer ${ }^{4}$ vapor pressure correlation and the estimated normal boiling point in PREDICT.
As with glucose, the heat of vaporization was set at an arbitrarily low value and the $\Delta \mathrm{H}_{\mathrm{F}}$ (IG) was back calculated using that heat of $\mathrm{M}$ vaporization and the literature value of heat of combustion (561.5 $\left.\mathrm{Kcal} / \mathrm{mole}^{6}\right)$. See Table 3 for a comparison of the original $\Delta \mathrm{H}_{C}$ and $\mathrm{M}$ that back calculated from Aspen.

\section{Temperature-Correlated Properties}

\section{Properties}

Vapor Pressure

IG Heat Capacity

Heat of Vaporization

Liquid Density

Liquid Heat Capacity

\section{(Quality Code) Methodology}

Estimated using the Pitzer ${ }^{4}$ corresponding states method with the above critical properties and fit to the Aspen+ PLXANT extended Antoine model.

Used a constant value for solid glucose at $20^{\circ} \mathrm{C}$ from the literature ${ }^{6}$ and assumed it was the same as the liquid heat capacit:. Using the heat of vaporization listed below, a single parameter in this equation was adjusted to the match the liquid heat capacity.

Set to an arbitrarily low value of $1 \mathrm{Kcal} / \mathrm{mole}\left(4.1868 \times 10^{6}\right)$ at $298 \mathrm{~K}$. The standard exponent for the Watson? equation of 0.38 was'used with the set value at $298 \mathrm{~K}$ in the Aspen DHVLWT (Watson) correlation. The Aspen single parameter in the Rackett ${ }^{3}$ was regressed using the literature ${ }^{9}$ data for glucose water solutions on a mass basis $(\mathrm{g} / \mathrm{L})$ and water data from the Aspen PURECOMP database. The results of this regression are given in Table 5 . 


\begin{tabular}{|c|c|c|c|c|c|c|c|c|c|c|c|}
\hline \multicolumn{12}{|l|}{\begin{tabular}{|l} 
Table 5. \\
.
\end{tabular}} \\
\hline \begin{tabular}{|l|} 
Mole \\
Frac \\
H2O
\end{tabular} & \begin{tabular}{|l|} 
Density \\
Data \\
g/cc
\end{tabular} & \begin{tabular}{|l|} 
Density \\
Estimate \\
g/cc
\end{tabular} & Std-Dev & \begin{tabular}{|l} 
Absolute \\
Diff.
\end{tabular} & \begin{tabular}{|l} 
Percent \\
Diff.
\end{tabular} & $\begin{array}{l}\text { Mole } \\
\text { Frac } \\
\text { H2O }\end{array}$ & \begin{tabular}{|l|} 
Density \\
Data \\
|g/cc
\end{tabular} & \begin{tabular}{|l|} 
Density \\
Estimated \\
g/cc
\end{tabular} & Std-Dev & \begin{tabular}{|l} 
Absolute \\
Diff.
\end{tabular} & \begin{tabular}{|l} 
Percent \\
Diff.
\end{tabular} \\
\hline 0.9995 & 1.0001 & 1.00001 & $11.00 \mathrm{E}-02$ & $|-8.63 E-05|$ & -8.63E-03 & 0.98131 & 1.0624 & 1.05752 & $1.06 \mathrm{E}-02$ & $-4.88 \mathrm{E}-03$ & -0.45941 \\
\hline \begin{tabular}{|l|}
0.99899 \\
\end{tabular} & 1.002 & 1.00172 & $1.00 \mathrm{E}-02$ & $|-2.84 E-04|$ & $\mid-2.83 E-02$ & 0.97993 & 1.0667 & 1.06159 & 1.07E-02 & $-5.11 \mathrm{E}-03$ & -0.47887 \\
\hline \begin{tabular}{|l|}
0.99848 \\
\end{tabular} & 1.0039 & 1.00343 & $1.00 \mathrm{E}-02$ & $|-4.74 E-04|$ & $-4.72 E-02$ & 0.97852 & 1.071 & 1.06571 & $1.07 \mathrm{E}-02$ & $-5.29 \mathrm{E}-03$ & -0.49362 \\
\hline \begin{tabular}{|l|}
0.99796 \\
\end{tabular} & 1.0058 & 1.00515 & $1.01 \mathrm{E}-02$ & $|-6.50 E-04|$ & $\mid-6.46 E-02$ & 0.97708 & 1.0753 & 1.06988 & $1.08 \mathrm{E}-02$ & $-5.42 \mathrm{E}-03$ & -0.50394 \\
\hline \begin{tabular}{|l|}
0.99744 \\
\end{tabular} & 1.0078 & 1.00688 & $11.01 \mathrm{E}-02$ & $|-9.22 E-04|$ & $|-9.15 E-02|$ & 0.97561 & 1.0797 & 1.0741 & $1.08 \mathrm{E}-02$ & $-5.60 \mathrm{E}-03$ & $-\overline{0.51848}$ \\
\hline \begin{tabular}{|l|}
0.99692 \\
\end{tabular} & 1.0097 & 1.00862 & $11.01 \mathrm{E}-02$ & $|-1.08 \mathrm{E}-03|$ & $|-0.10706|$ & 0.97257 & 1.0884 & 1.08269 & $1.09 \mathrm{E}-02$ & $-5.71 E-03$ & -0.52493 \\
\hline \begin{tabular}{|l|}
0.99639 \\
\end{tabular} & 1.0116 & 1.01037 & $11.01 \mathrm{E}-02$ & $|-1.23 \mathrm{E}-03|$ & $-0.12154 \mid$ & 0.96939 & 1.0973 & 1.09147 & $1.10 \mathrm{E}-02$ & $-5.83 \mathrm{E}-03$ & -0.53108 \\
\hline \begin{tabular}{|l|}
0.99585 \\
\end{tabular} & 1.0136 & 1.01213 & $11.01 \mathrm{E}-02$ & $|-1.47 E-03|$ & -0.14515 & 0.96606 & 1.1063 & 1.10047 & $1.11 \mathrm{E}-02$ & $-5.83 \mathrm{E}-03$ & -0.52699 \\
\hline 0.99531 & \begin{tabular}{|l|}
1.0155 \\
\end{tabular} & 1.0139 & $11.02 \mathrm{E}-02$ & $|-1.60 \mathrm{E}-03|$ & -0.15755 & 0.96257 & 1.1154 & 1.10968 & $1.12 \mathrm{E}-02$ & $-5.72 \mathrm{E}-03$ & -0.51315 \\
\hline $\mid 0.99477$ & 1.0175 & 1.01568 & $1.02 \mathrm{E}-02$ & $|-1.82 E-03|$ & -0.17908 & 0.95891 & 1.1246 & 1.1191 & $1.12 \mathrm{E}-02$ & \begin{tabular}{|l|} 
\\
\end{tabular} & -0.48891 \\
\hline \begin{tabular}{|l|}
0.99421 \\
\end{tabular} & 1.0194 & 1.01747 & $1.02 \mathrm{E}-02$ & $|-1.93 E-03|$ & -0.18948 & 0.95506 & 1.134 & 1.12875 & $1.13 \mathrm{E}-02$ & $-5.25 E-03$ & -0.46317 \\
\hline \begin{tabular}{|l|}
0.99366 \\
\end{tabular} & \begin{tabular}{|l|}
1.0214 \\
\end{tabular} & 1.01927 & $1.02 \mathrm{E}-02$ & $|-2.13 E-03|$ & -0.20869 & 0.95101 & 1.1434 & 1.13862 & $1.14 \mathrm{E}-02$ & $-4.78 E-03$ & -0.41832 \\
\hline 0.9931 & \begin{tabular}{|l|}
1.0234 \\
\end{tabular} & 1.02108 & $1.02 \mathrm{E}-02$ & $|-2.32 \mathrm{E}-03|$ & -0.22661 & 0.94675 & 1.1529 & 1.14872 & $1.15 \mathrm{E}-02$ & $-4.18 \mathrm{E}-03$ & $\overline{-0.36294}$ \\
\hline \begin{tabular}{|l|}
0.99253 \\
\end{tabular} & \begin{tabular}{|l|}
1.0254 \\
\end{tabular} & 1.0229 & $1.03 \mathrm{E}-02$ & $|-2.50 \mathrm{E}-03|$ & -0.24389 & 0.94225 & 1.1626 & 1.15905 & $1.16 \mathrm{E}-02$ & $-3.55 \mathrm{E}-03$ & -0.30577 \\
\hline \begin{tabular}{|l|}
0.99196 \\
\end{tabular} & \begin{tabular}{|l|}
1.0274 \\
\end{tabular} & 1.02473 & $1.03 \mathrm{E}-02$ & $|-2.67 \mathrm{E}-03|$ & -0.25962 & 0.9375 & 1.1724 & 1.16961 & $1.17 \mathrm{E}-02$ & $-2.79 \mathrm{E}-03$ & $\overline{-0.23814}$ \\
\hline \begin{tabular}{|l|}
0.99138 \\
\end{tabular} & \begin{tabular}{|l|}
1.0294 \\
\end{tabular} & 1.02657 & $1.03 \mathrm{E}-02$ & $|-2.83 E-03|$ & \begin{tabular}{|c|}
-0.27476 \\
\end{tabular} & 0.93248 & 1.1823 & 1.18041 & $1.18 \mathrm{E}-02$ & $-1.89 \mathrm{E}-03$ & -0.16019 \\
\hline 0.9908 & 1.0314 & 1.02843 & $1.03 \mathrm{E}-02$ & $|-2.97 \mathrm{E}-03|$ & -0.28839 & 0.92715 & 1.1924 & 1.19144 & $1.19 \mathrm{E}-02$ & $-9.60 \mathrm{E}-04$ & $-8.05 \mathrm{E}-$ \\
\hline \begin{tabular}{|l|}
0.99021 \\
\end{tabular} & \begin{tabular}{|l|}
1.0334 \\
\end{tabular} & 1.03029 & $1.03 \mathrm{E}-02$ & $|-3.11 \mathrm{E}-03|$ & $\mid-0.30117$ & 0.9215 & 1.2026 & 1.20271 & $1.20 \mathrm{E}-02$ & $1.06 \mathrm{E}-04$ & $8.81 \mathrm{E}-$ \\
\hline \begin{tabular}{|l|}
0.98961 \\
\end{tabular} & \begin{tabular}{|l|}
1.0354 \\
\end{tabular} & 1.03216 & $1.04 \mathrm{E}-02$ & $|-3.24 E-03|$ & \begin{tabular}{|c|}
-0.3128 \\
\end{tabular} & 0.9155 & 1.213 & 1.21421 & $1.21 \mathrm{E}-02$ & $1.20 \mathrm{E}-03$ & 9.93E- \\
\hline \begin{tabular}{|l|}
0.98901 \\
\end{tabular} & \begin{tabular}{|l|}
1.0375 \\
\end{tabular} & 1.03405 & $1.04 \mathrm{E}-02$ & $|-3.45 E-03|$ & -0.33292 & 0.90909 & 1.2235 & 1.22593 & $1.22 \mathrm{E}-02$ & $2.43 \mathrm{E}-03$ & 0.19859 \\
\hline \begin{tabular}{|l|l|}
0.98779 \\
\end{tabular} & 1.0416 & 1.03785 & $11.04 \mathrm{E}-02$ & $|-3.76 \mathrm{E}-03|$ & -0.36054 & 0.90226 & 1.2342 & 1.23787 & $1.23 \mathrm{E}-02$ & $3.67 \mathrm{E}-03$ & 0.29769 \\
\hline \begin{tabular}{|l|}
0.98655 \\
\end{tabular} & \begin{tabular}{|l|}
1.0457 \\
\end{tabular} & 1.04169 & $1.05 \mathrm{E}-02$ & $\mid-4.01 \mathrm{E}-03$ & -0.38333 & 0.89495 & 1.2451 & \begin{tabular}{|c|}
1.25003 \\
\end{tabular} & $1.25 \mathrm{E}-02$ & $4.93 \mathrm{E}-03$ & 0.39573 \\
\hline $\mid 0.98528$ & \begin{tabular}{|l|}
1.0498 \\
\end{tabular} & 1.04558 & $1.05 \mathrm{E}-02$ & $-4.22 \mathrm{E}-03$ & -0.4021 & 0.8871 & 1.2562 & 1.26238 & $1.26 \mathrm{E}-02$ & $6.18 \mathrm{E}-03$ & 0.49187 \\
\hline \begin{tabular}{|l|}
0.98398 \\
\end{tabular} & 1.054 & 1.04951 & $1.05 \mathrm{E}-02$ & $-4.49 \mathrm{E}-03$ & -0.42565 & 0.87866 & 1.2676 & 1.27491 & $1.27 \mathrm{E}-02$ & $7.31 \mathrm{E}-03$ & 0.57665 \\
\hline \begin{tabular}{|l|}
0.98266 \\
\end{tabular} & 1.0582 & 1.0535 & $11.06 \mathrm{E}-02$ & $|-4.71 \mathrm{E}-03|$ & -0.44467 & 0.86957| & 1.2793 & 1.2876 & $1.28 \mathrm{E}-02$ & $8.29 \mathrm{E}-03$ & 0.64839 \\
\hline ROOTN & $\overline{A N ~ S C}$ & ARE DE & VIATION & $=$ & 87 & & & & & & \\
\hline AVERAC & $=D E V$ & ATION & & $=$ & -0.2 & & & & & & \\
\hline AVERAG & E ABSO & LUTE DE & VIATION & $=$ & $0.3407739 \mathrm{E}$ & & & & & & \\
\hline MAXIMUN & M DEVIA & ITION & & $=$ & $0.8294807 \mathrm{E}$ & & & & & & \\
\hline RMS REL & LATIVE L & DEVIATIOI & & $=$ & $0.3518716 \mathrm{E}$ & & & & & & \\
\hline AVG. ABS & S. REL. [ & DEVIATIO & & $=$ & $0.3078164 \mathrm{E}$ & & & & & & \\
\hline
\end{tabular}

\section{Cellulose}

Cellulose is considered to be a solid throughout the process and will never be in solution. Additionally, cellulose is a polymer, but its molecular weight formula will be taken as the repeat unit only. The other properties are determined on a weight basis and then converted to mole basis for the database, using the molecular weight of a repeat unit. 


\section{Point Properties}

\section{Properties (Quality Code) Methodology}

Molecular Weight

Solid Heat of

Formation@298.15 K
(7) Calculated directly:

(6) Using the a literature value for $\Delta \mathrm{H}_{\mathrm{c}}{ }^{10}$ the heat of formation was back calculated. See Table 3 for the original values of $\Delta H_{c}$.

\section{Temperature Correlated Properties}

\section{Properties (Quality Code) Methodology}

Solid Heat Capacity

Solid Density

mass basis was used.

A literature value for $\operatorname{starch}^{11}$ was used on a mass basis.

Xylan

Xylan is considered to be a solid throughout the process and will never be in solution. Additionally, xylan is a polymer, but its molecular weight formula will be taken as the repeat unit only. The other properties are determined on a weight basis and then converted to mole basis for the database, using the molecular weight of a repeat unit.

\section{Point Properties}

Properties

Molecular Weight

Solid Heat of

Formation $\underline{a}, 298.15 \mathrm{~K}$

\section{(Quality Code) Methodology}

Calculated directly.

Assumed that the ratio of the $\Delta \mathrm{H}_{\mathrm{c}}$ of glucose to xilose would be the same as that for the ratio of cellulose to xylan. Using the glucose to xylose $\Delta \mathrm{H}_{\mathrm{c}}$ ratio and the $\Delta \mathrm{H}_{\mathrm{t}}$ from above for cellulose, the $\Delta \mathrm{H}_{\mathrm{c}}$ for xylan was approximated. From the $\Delta \mathrm{H}_{\mathrm{c}}$, the heat of formation was calculated.

\section{Temperature-Correlated Properties}

\section{Properties (Quality Code) Methodology}

Solid Heat Capacity

Solid Density
A literature polynomial ${ }^{10}$ for cellulose from loblolly pine wood on a mass basis was used.

A literature value for $\operatorname{starch}^{11}$ was used on a mass basis. 


\section{Lignin}

Lignin is considered to be a solid throughout the process and will never be in solution.

\section{Point Properties}

\section{Properties (Quality Code) Methodology}

Molecular Weight

(7) Calculated directly.

Solid Heat of

Used $\Delta \mathrm{H}_{\mathrm{c}}$ value supplied by Riley ${ }^{12}$ to calculate the heat of formation. $\mathrm{M}$

Formation@298.15 K The $\Delta \mathrm{H}_{\mathrm{c}}$ of Riley is similar to a value given by the literature for softwood. The softwood literature ${ }^{10}$ is $11340 \mathrm{BTU} / \#$ and the value from Riley is $11476 \mathrm{BTU} / \#$.

\section{Temperature-Correlated Properties}

\section{Properties (Quality Code) Methodology}

Solid Heat Capacity (9) Used literature value for polynomial ${ }^{10}$.

Solid Density (3) Simply assume $1.5 \mathrm{~g} / \mathrm{cc}$ (similar to starch).

\section{Cellulase (Enzyme)}

Cellulase is considered to be a solid throughout the process and will never be in solution.

\section{Point Properties}

Properties (Quality Code) Methodology

Molecular Weight

Solid Heat of
Calculated directly.

Used $\Delta \mathrm{H}_{\mathrm{c}}$ value supplied by Putsche ${ }^{2}$ to calculate heat of formation. Putsche calculated the $\Delta \mathrm{H}_{\mathrm{c}}$ using the approximation method of Bailey and Ollis ${ }^{13}$.

\section{Temperature-Correlated Properties}

\section{Properties (Quality Code) Methodology}

Solid Heat Capacity

Solid Density
Estimated using Kopp's rule ${ }^{6}$.

Simply assume $1.5 \mathrm{~g} / \mathrm{cc}$ (similar to starch). 


\section{Biomass (Cell Mass)}

Biomass is considered to be a solid throughout the process and will never be in solution.

Point Properties

Properties (Quality Code) Methodology

Molecular Weight (7) Calculated directly.

Solid Heat of (6)

Formation@298.15 K

Used $\Delta \mathrm{H}_{\mathrm{c}}$ value supplied by Putsche $\mathrm{e}^{2}$ to calculate heat of formation. Putsche calculated the $\Delta \mathrm{H}_{\mathrm{c}}$ using the approximation method of Bailey and Ollis ${ }^{13}$.

Temperature-Correlated Properties

Properties (Quality Code) Methodology

Solid Heat Capacity (4) Estimated using Kopp's rule ${ }^{6}$.

Solid Density

Simply assume $1.5 \mathrm{~g} / \mathrm{cc}$ (similar to starch).

\section{Zymo (Bacterium)}

Zymo is considered to be a solid throughout the process and will never be in solution.

\section{Point Properties}

Properties (Quality Code) Methodology

Molecular Weight

Solid Heat of

Formation@298.15 K

Calculated directly

Estimated $\Delta \mathrm{H}_{\mathrm{c}}$ using a crude method of Bailey and Ollis ${ }^{13}$

and then calculated the heat of formation.

Temperature-Correlated Properties

Properties (Quality Code) Methodology

Solid Heat Capacity

Solid Density

Estimated using Kopp's rule 6 .

Simply assume $1.5 \mathrm{~g} / \mathrm{cc}$ (similar to starch).

\section{Solslds (Soluble Solids)_Poplar Biomass}

Solslds are the nonidentifiable solids that will be dissolved in aqueous solutions throughout the simulation. Therefore, they will never exist as a pure liquid in the process. The properties listed here are NOT intended for use with pure components, or even with concentrated solutions. The vapor pressure is low enough (the normal boiling point has been estimated to be higher than $800 \mathrm{~K}$ ) such that the solslds will never be flashed into the vapor stream. 


\section{Point Properties}

$\begin{array}{lc}\text { Properties } & \text { (Quality } \\ \text { Molecular Weight } & (7) \\ \text { Critical Temperature } & (1) \\ \text { Critical Pressure } & (1) \\ \text { Critical Volume } & (1) \\ \text { Acentric Factor } & (1) \\ \text { IG Heat of Formation } & (4) \\ \quad \text { @ 298.15 K } & \end{array}$

Methodology

Calculated directly.

Used the value of glucose.

Used the value of glucose.

Used the value of glucose.

Used the value of glucose.

$\Delta \mathrm{H}_{\mathrm{c}}$ value calculated to match the $\Delta \mathrm{H}_{\mathrm{c}}$ of poplar biomass and its identifiable components. This was verified using a crude method of Bailey and $\mathrm{Ollis}^{13}$. This value was then used to calculated the heat of formation of the liquid. A small value of $1 \mathrm{kcal} / \mathrm{mole}$ was assumed for the heat of vaporization and the IG heat of formation was calculated.

Temperature-Correlated Properties

\begin{tabular}{|c|c|c|}
\hline Properties & (Quality Code) & Methodology \\
\hline Vapor Pressure & (1) & Used the value of glucose. \\
\hline IG Heat Capaciț & (1) & $\begin{array}{l}\text { Used a constant value for solid glucose at } 20^{\circ} \mathrm{C} \text { from the literature }{ }^{6} \text { and } \\
\text { assumed it was the same as the liquid heat capacity. Using the heat of } \\
\text { vaporization listed below, a single parameter in this equation was } \\
\text { adjusted to the match the liquid heat capacity. }\end{array}$ \\
\hline Heat of Vaporization & $(0)$ & Assumed an arbitrary low value of $1 \mathrm{kcal} / \mathrm{mole}$ at $298 \mathrm{~K}$. \\
\hline Liquid Density & $(0)$ & $\begin{array}{l}\text { Assuming a value of water }(1 \mathrm{~g} / \mathrm{cc}) \text { the Rackett parameter was back } \\
\text { calculated using the above critical properties and molecular weight. }\end{array}$ \\
\hline Liquid Heat Capacity & (3) & Used value for glucose on a mass basis. \\
\hline
\end{tabular}

\section{Solunkn (Unknown Soluble Solids)}

Solunkn is an unhnown compound similar to xylose that will be dissolved in aqueous solutions through- out the simulation. Therefore, it will never exist as a pure liquid in the process. The properties listed here are NOT intended for use with pure compounds or even with concentrated solutions. The vapor pressure is sufficiently low (the normal boiling point has been estimated to be higher than $800 \mathrm{~K}$ ) such that the solunkn will never be flashed into the vapor stream. 


\section{Point Properties}

Properties

Molecular Weight

Critical Temperature

Critical Pressure

Critical Volume

Acentric Factor

IG Heat of Formation

(a) $298.15 \mathrm{~K}$
(Quality Code) Methodology

(7) Calculated directly.

(1) Used the value of xylose.

(1) Used the value of xylose.

(1) Used the value of xylose.

(1) Used the value of xylose.

(4) Estimated $\Delta \mathrm{H}_{\mathrm{c}}$ using a crude method of Bailey and Ollis ${ }^{13}$ and then calculated the heat of formation of the liquid. A small value of $1 \mathrm{kcal} /$ mole was assumed for the heat of vaporization and the IG heat of formation was calculated.

\section{Temperature-Correlated Properties}

\section{Properties}

Vapor Pressure

IG Heat Capacity

Heat of Vaporization

Liquid Density.

Liquid Heat Capacity

\section{(Quality Code)}

\section{Methodology}

Used the value of glucose.

Used a constant value for solid glucose at $20^{\circ} \mathrm{C}$ from the literature ${ }^{6}$ and assumed it was the same as the liquid heat capacity. Using the heat of vaporization listed below, a single parameter in this equation was adjusted to match the liquid heat capacity. Assumed an arbitrary low value of $1 \mathrm{kcal} / \mathrm{mole}$ at $298 \mathrm{~K}$.

Assuming a value of water $(1 \mathrm{~g} / \mathrm{cc})$ the Rackett parameter was back calculated using the above critical properties and molecular weight. Used value for glucose on a mass basis.

\section{Gypsum}

Gypsum is considered to be a solid throughout the process and will never be in solution.

\section{Point Properties}

\section{Properties}

Molecular Weight

Solid Heat of

Formation@298.15 K

Solid Free Energy of

Formation@298.15 K
(Quality Code) Methodology

Calculated directly.

Literature value ${ }^{14}$.

(9) Literature value ${ }^{14}$. 


\section{Temperature-Correlated Properties}

\begin{tabular}{|c|c|c|}
\hline Properties & (Quality Code) & Methodology \\
\hline Solid Heat Cap & (2) & Used literature value for $\mathrm{CaSO}_{4}{ }^{14}$. \\
\hline Solid Density & (9) & Literature value ${ }^{14}$. \\
\hline
\end{tabular}

\section{Acknowledgment}

This work was funded by the Biochemical Conversion Element of the Office of Fuels Development of the U.S. Department of Energy.

\section{References}

1. Radian Corporation. 1991. Biomass to Ethanol: Total Energy Cycle Analysis, NREL Subcontract Report, Austin, TX, RCN 213-185-01-00, November 22.

2. Putsche, V. 1996. "Proposed Methodologies for Calculating Call Mass and Cellulase Production Energetics," Interoffice Memo to Riley et al., January 18.

3. Joback, Kevin G. 1982. "A Unified Approach to Physical Property Estimation Using Multivariate Stastical Techniques," MS Thesis, MIT, June.

4. Pitzer, K.S.; D.Z. Lippman; R.F. Curl; C.M. Huggins; D.E. Peterson. 1955. "The Volumetric and Thermodynamic Properties of Fluids. II. Compressibility Factor, Vapor Pressure and Entropy of Vaporization," J. Am Chem. Soc. 77:3433.

5. Zwolinski, B.J.; R. Wilhoit. 1972. "Heats of Formation and Heats of Combustion" in American Institute of Physics Handbook, 3rd ed., D.E. Gray, ed., McGraw-Hill, New York, pp. 4-316-342.

6. Dean, J.A., ed. 1973. Lange's Handbook of Chemistry, 1lth ed., McGraw-Hill, New York, p. 9-126.

7. Watson, K.M. 1943. "Thermodynamics of the Liquid State, Generalized Prediction of Properties," Ind. Eng. Chem. 35:398.

8. Rackett, H.G. 1970. “Equation of State for Saturated Liquids," J. Chem. Eng. Data, 15(4):514.

9. Weast, R.C., ed. 1973. Handbook of Chemistry and Physics, 53rd ed., CRC Press, Cleveland, p. D192.

10. Domalski, E.S.; T.L. Jobe, Jr.; T. A. Milne. 1987. Thermodynamic Data for Biomass Materials and Waste Components, The American Society of Mechanical Engineers, New York, pp. 68-72.

11. Perry, R.H.; C.H. Chilton, eds. 1973. Chemical Engineers' Handbook, 5th ed., McGraw-Hill, New York, pp. 3-42. 
12. Riley, C. 1995. Personal communication, National Renewable Energy Laboratory, Golden, CO.

13. Bailey, J.E.; D.F. Ollis. 1986. Biochemical Engineering Fundamentals, 2nd ed., McGraw-Hill, New York, p. 294.

14. Robie, R.A.; B.S. Hemingway; J.R Fisher. 1979. Thermodynamic Properties of Minerals and Related Substances at $298.15 \mathrm{~K}$ and 1 Bar Pressure and at Higher Temperatures, U.S. Geological Survey Bulletin 1452, U.S. Government Printing Office, Washington, DC, pp. 25, 320. 


\section{APPENDIX A \\ ASPEN Plus DFMS (Data File Management System) Input File}

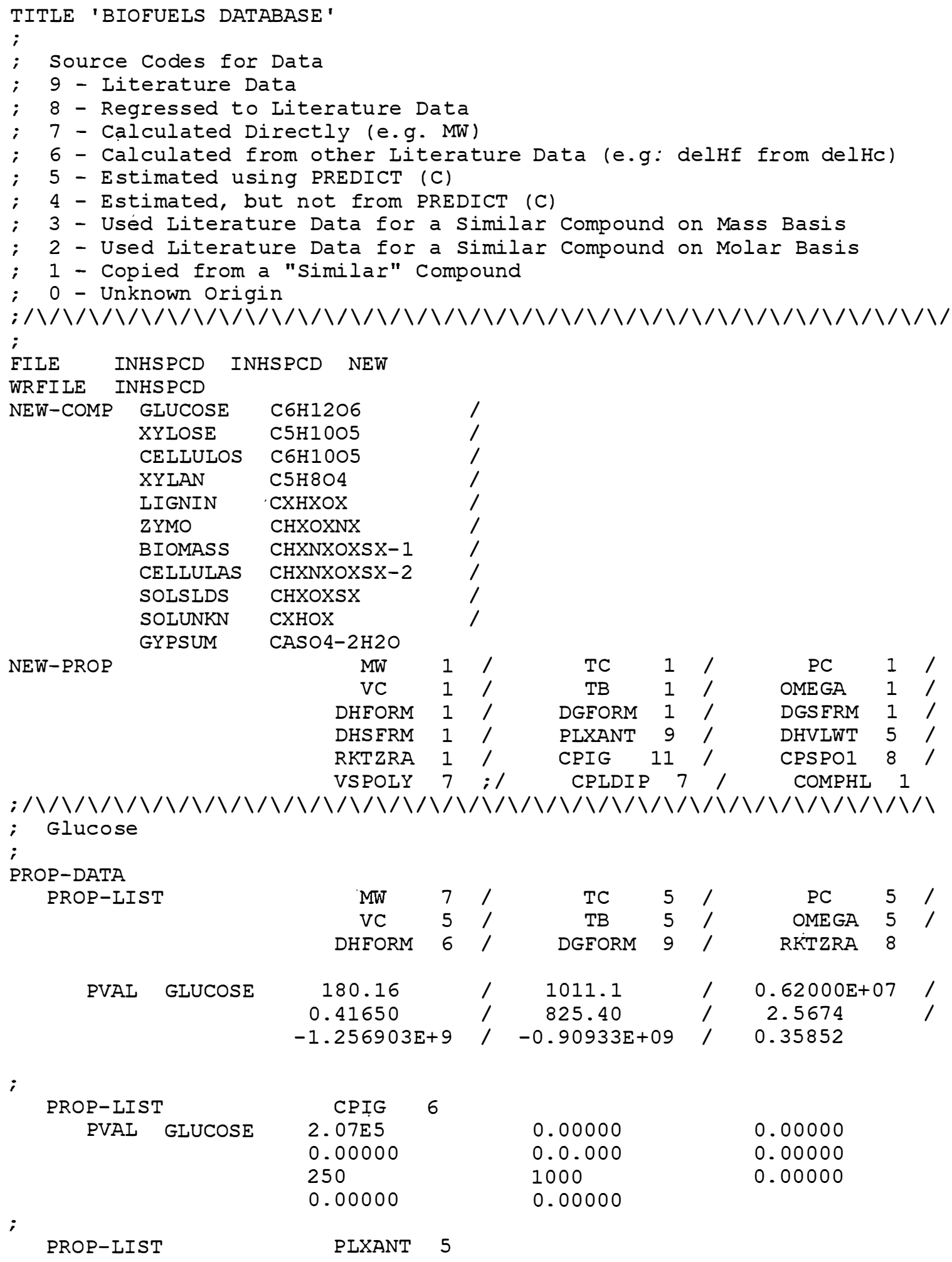




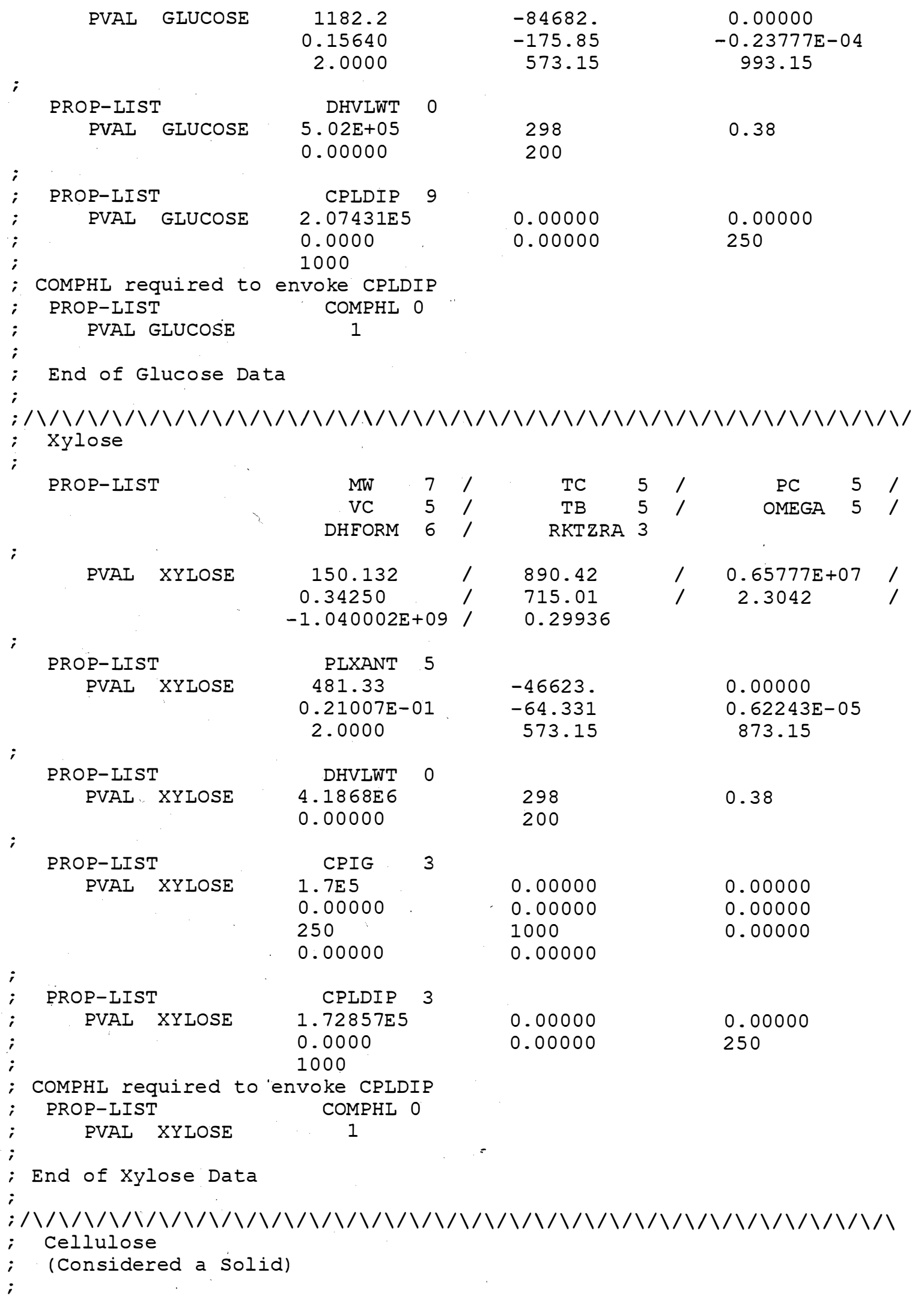




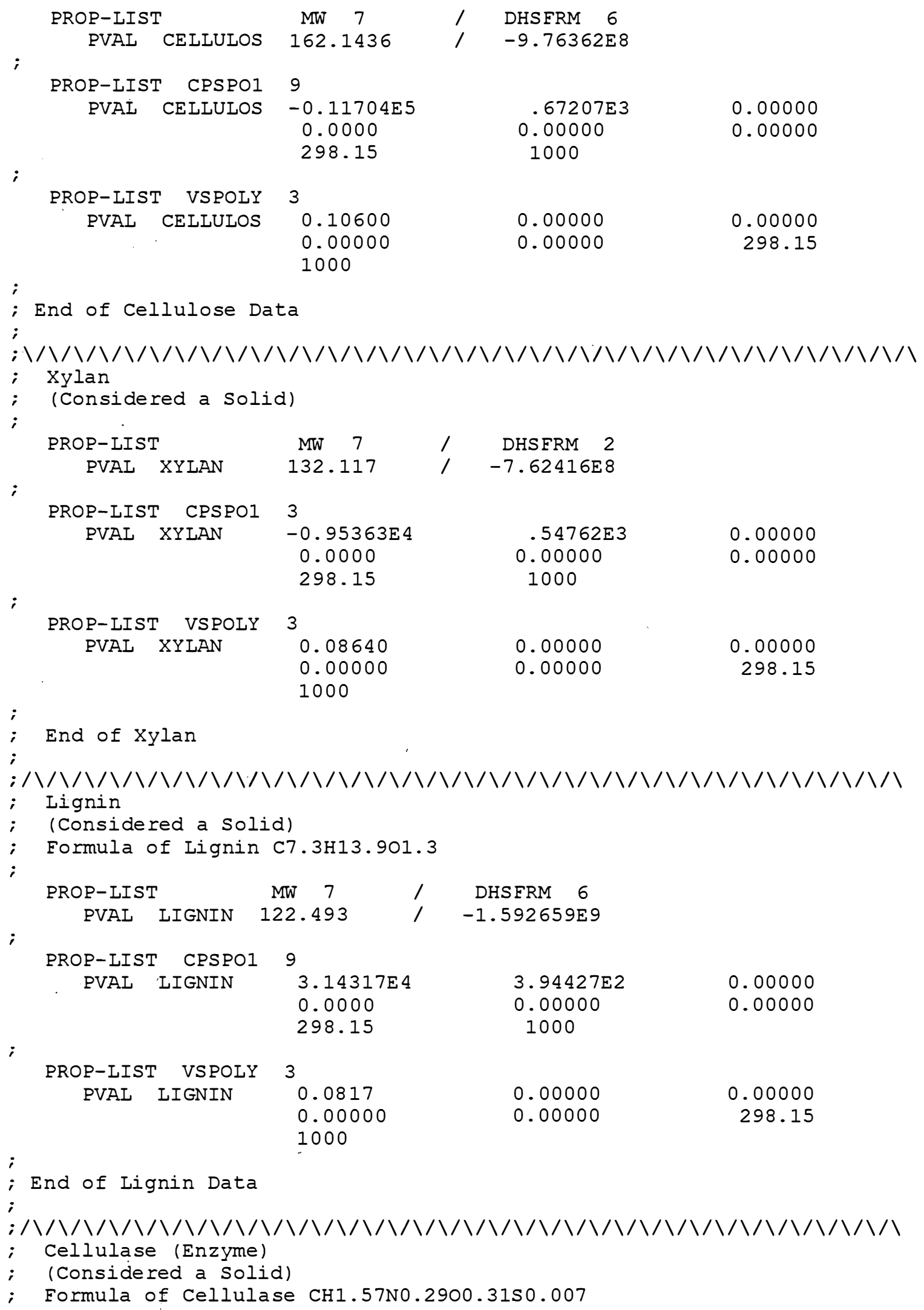




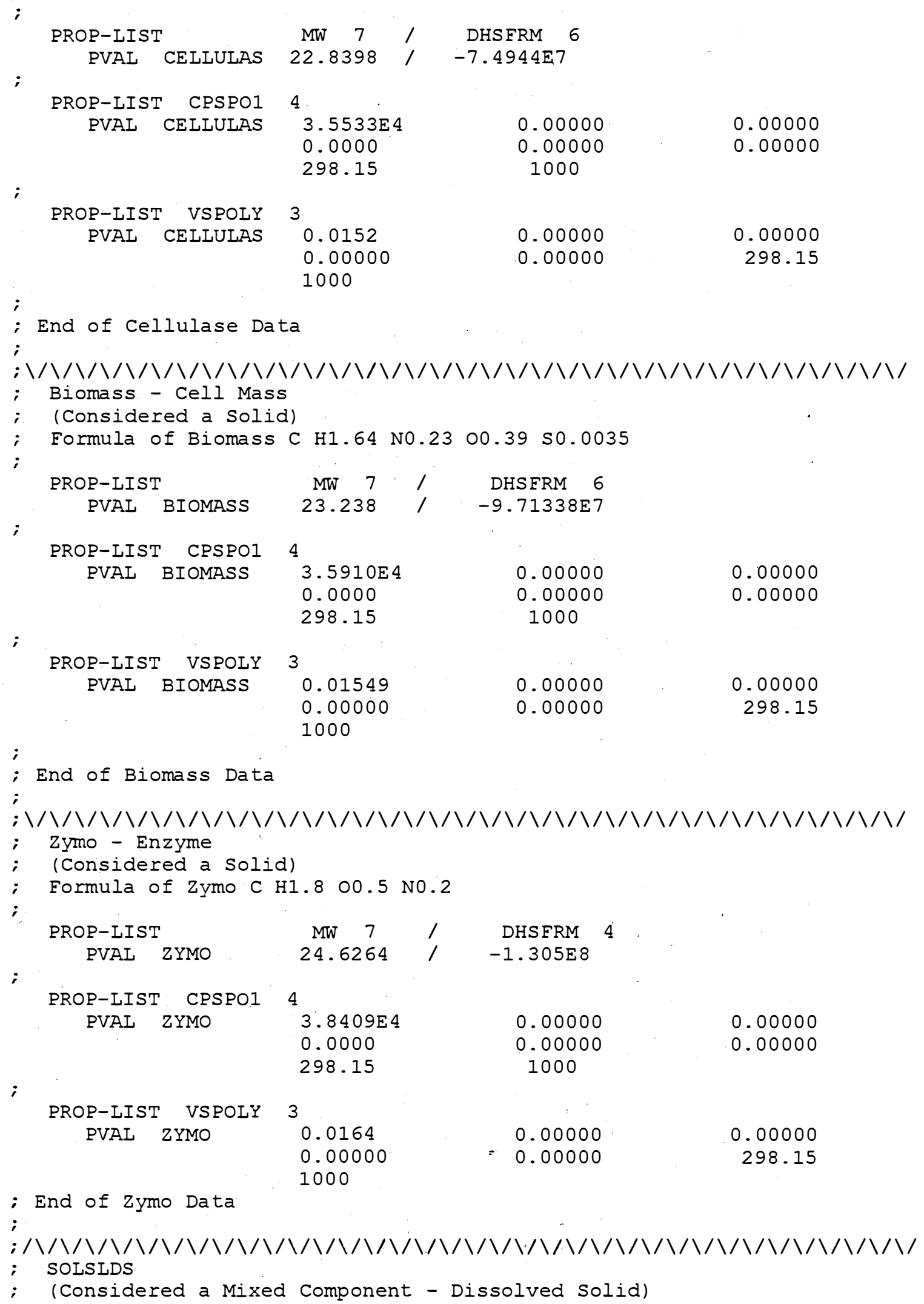




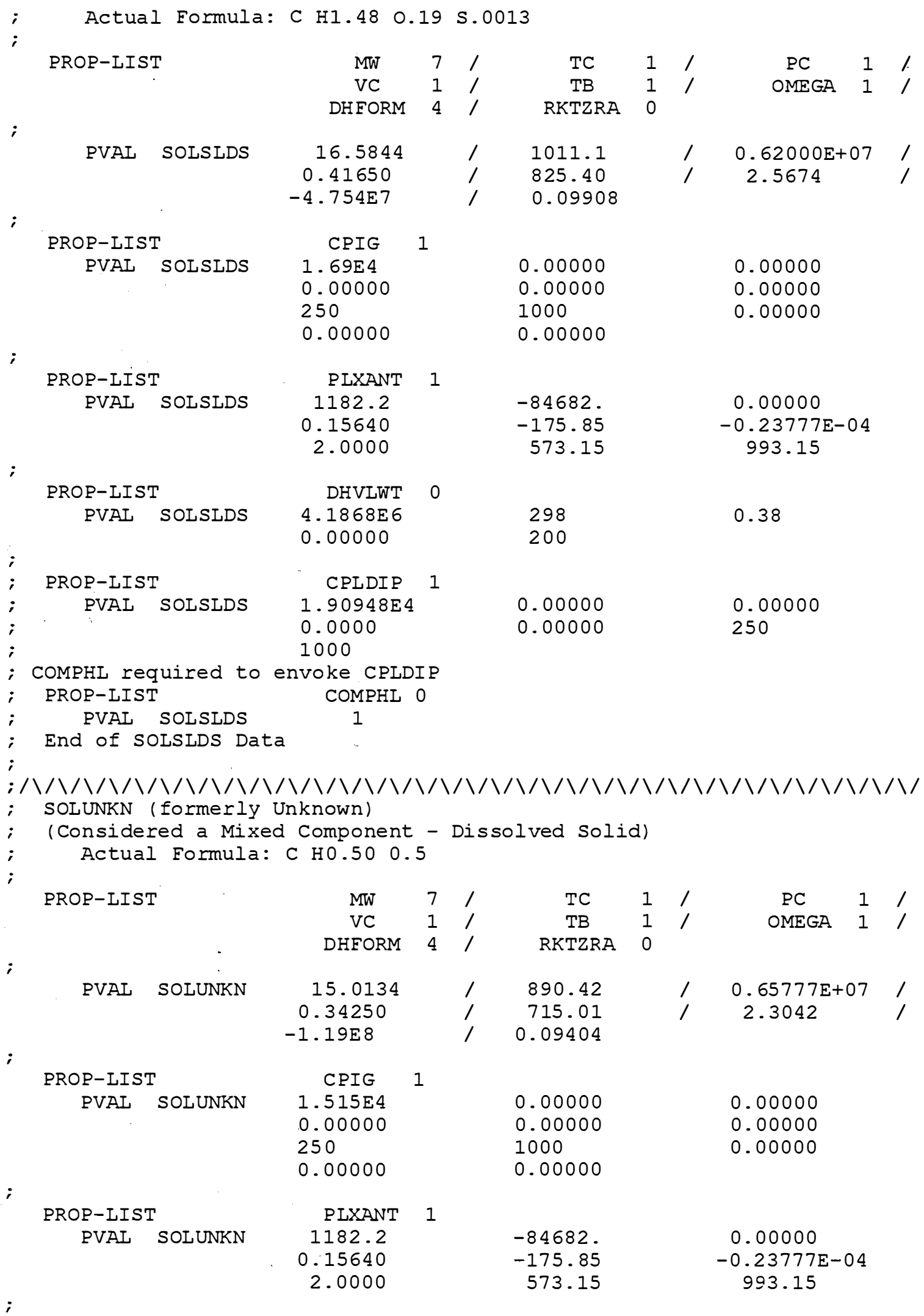




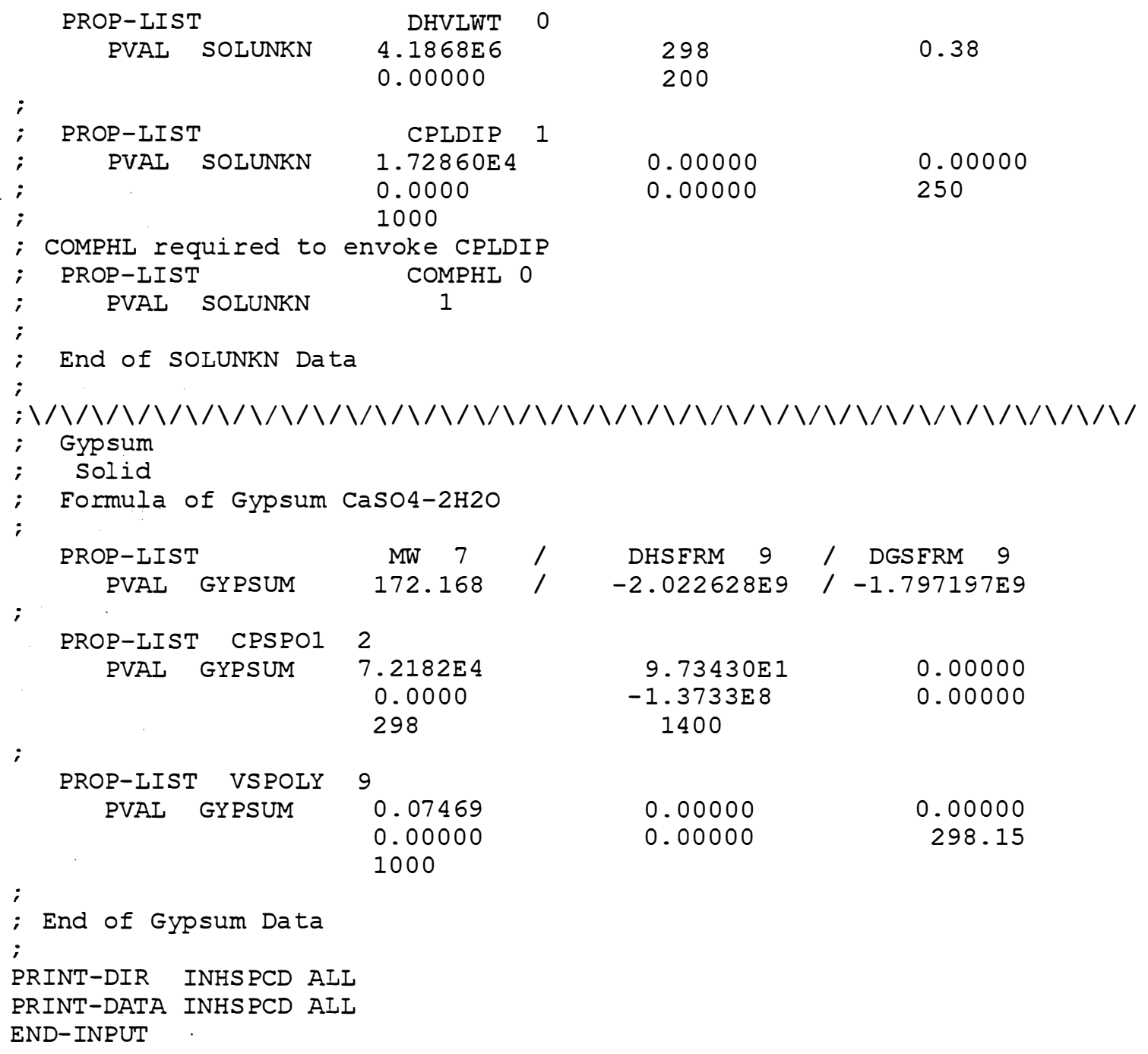




\section{APPENDLX B ASPEN Plus PROP-DATA Input File}

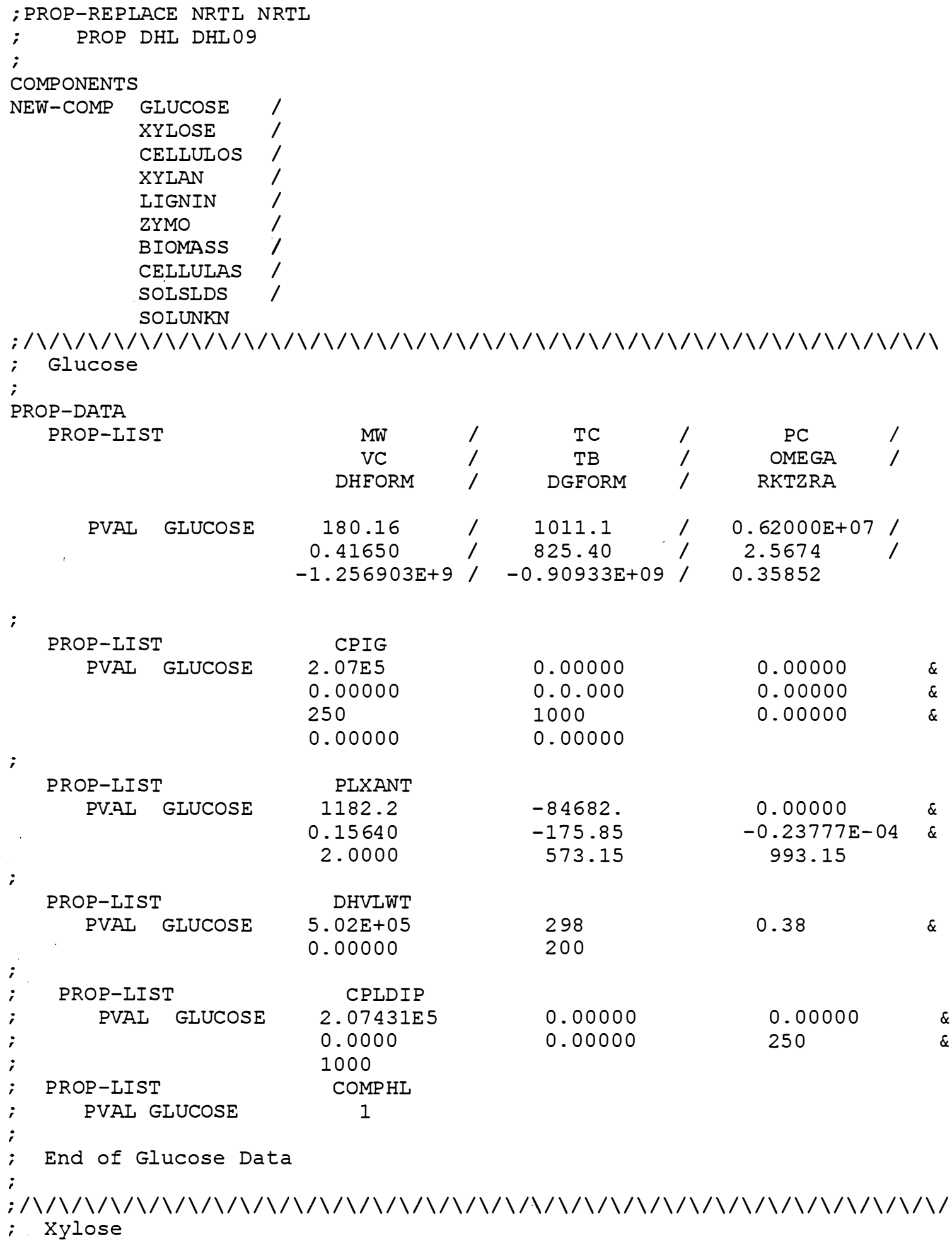

0.38

End of Glucose Data

; ハハハハハハハハハハハハハハハハハハハハハハハハハハハハハハハハハハ৷ xylose 


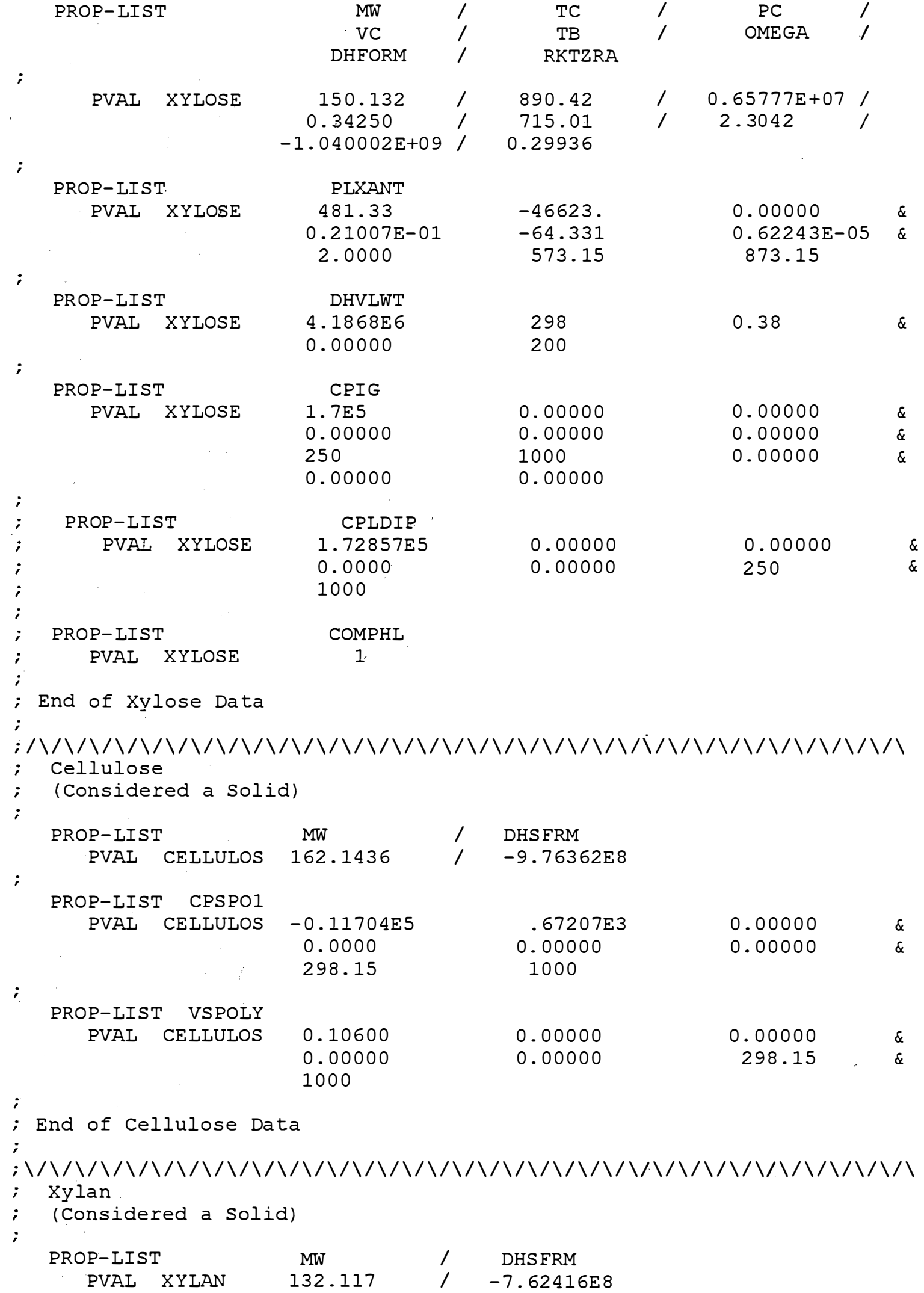

$\begin{array}{lrrr}0.10600 & 0.00000 & 0.00000 & \& \\ 0.00000 & 0.00000 & 298.15 & \& \\ 1000 & & & \end{array}$

End of Cellulose Data 


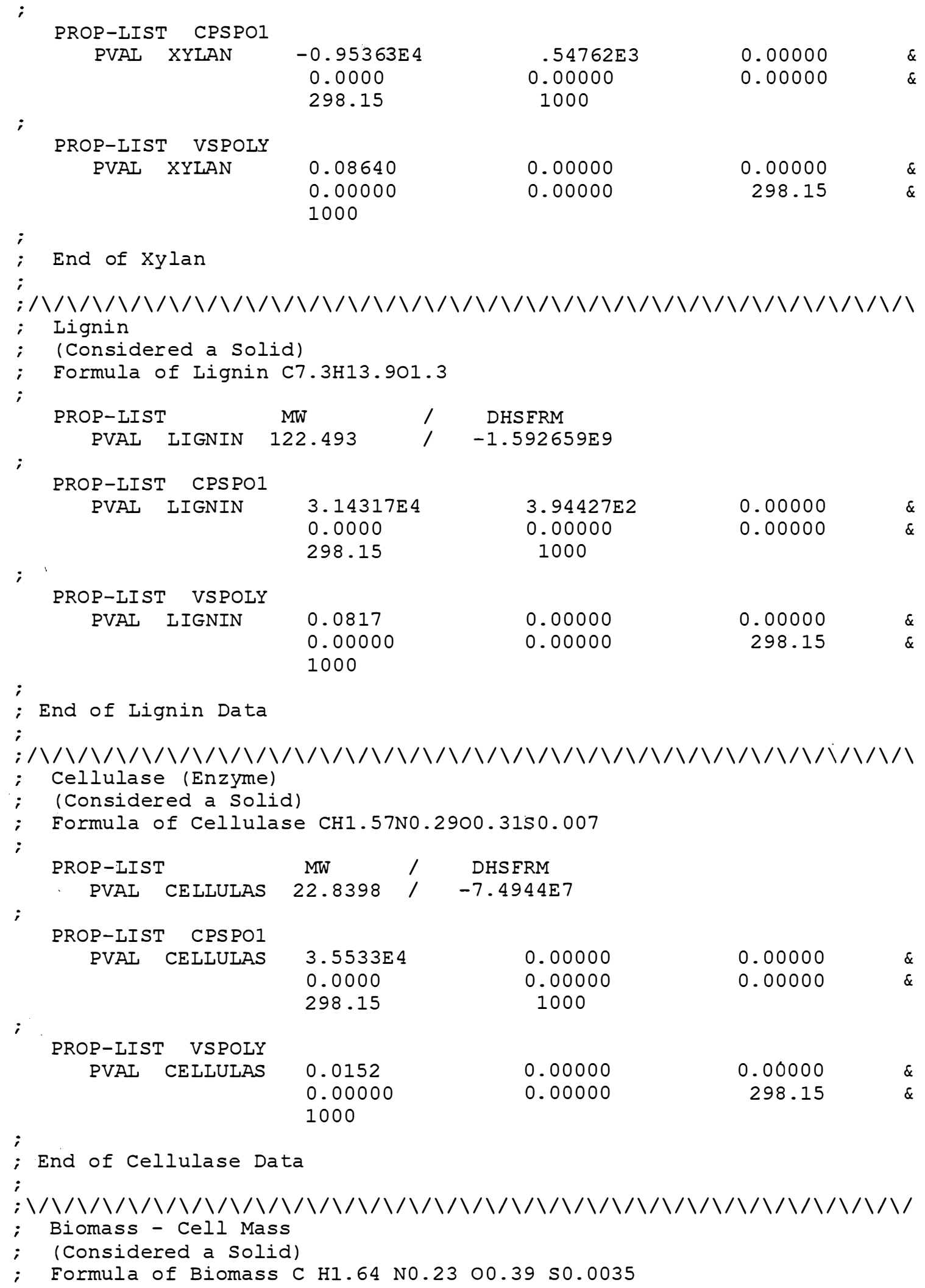

0.00000

0.00000

298.15

$\&$

0.00000

$\&$

;

; End of Xylan

;ハハハハハハハハハハハハハハハハハハハハハハハハハハハハハハハハハハハ

0.00000

0.00000

0.00000

298.15

$\&$

End of Lignin Data

;

;ハハハハハハハハハハハハハハハハハハハハハハハハハハハハハハハハハハハ

; Cellulase (Enzyme)

; (Considered a Solid)

; Formula of Cellulase CH1.57N0.2900.3150.007

;

PROP-IIST

PVAL CELLULAS $22.8398 / / .4944 \mathrm{E} 7$

;

PROP-LIST CPSPOI

PVAL CELLULAS

$\begin{array}{lccc}3.5533 E 4 & 0.00000 & 0.00000 & \& \\ 0.0000 & 0.00000 & 0.00000 & \& \\ 298.15 & 1000 & & \end{array}$

;

PROP-IIST VSPOLY PVAL CELLULAS

$\begin{array}{ll}0.0152 & 0.00000 \\ 0.00000 & 0.00000 \\ 1000 & \end{array}$

0.00000 298.15 


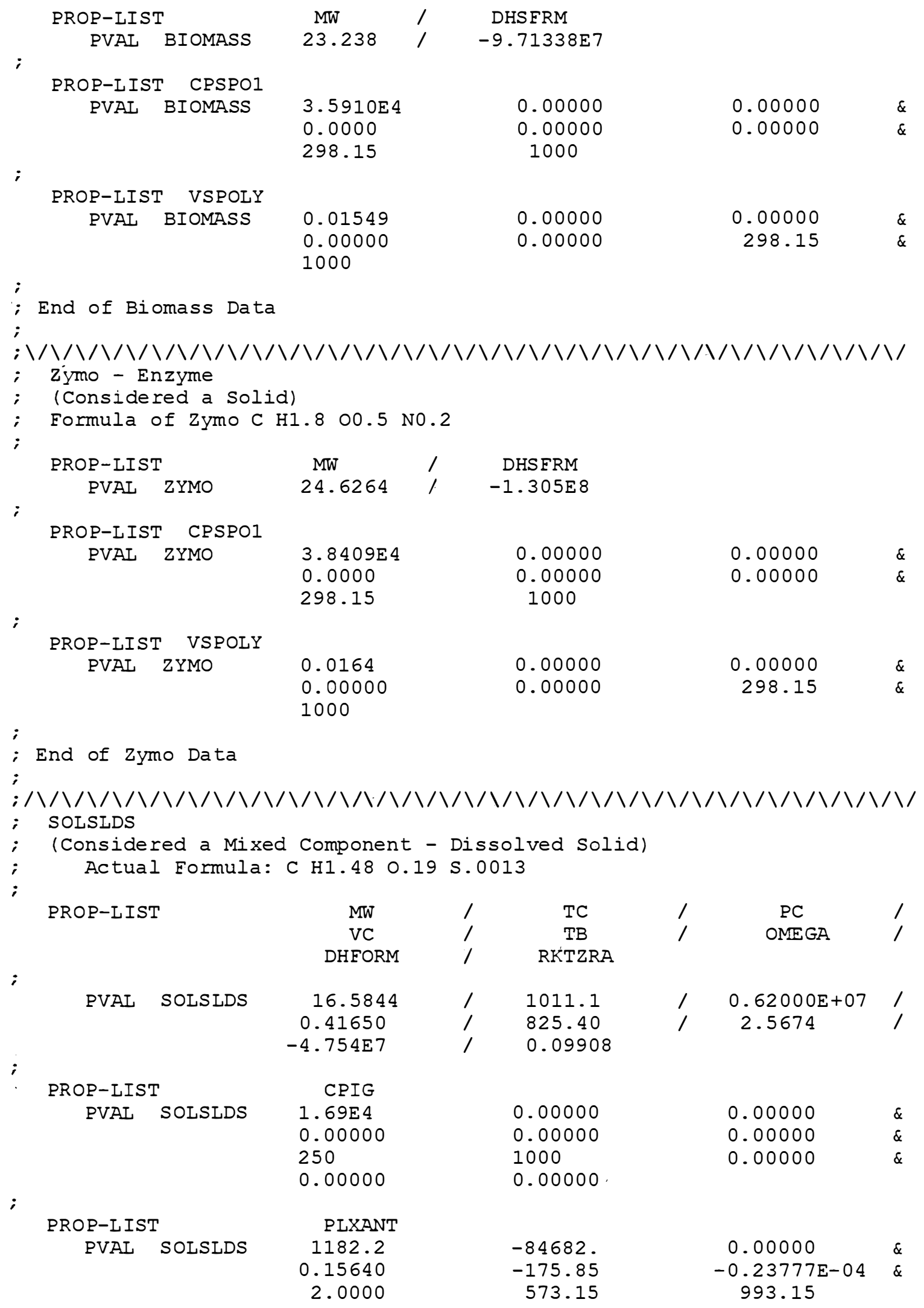




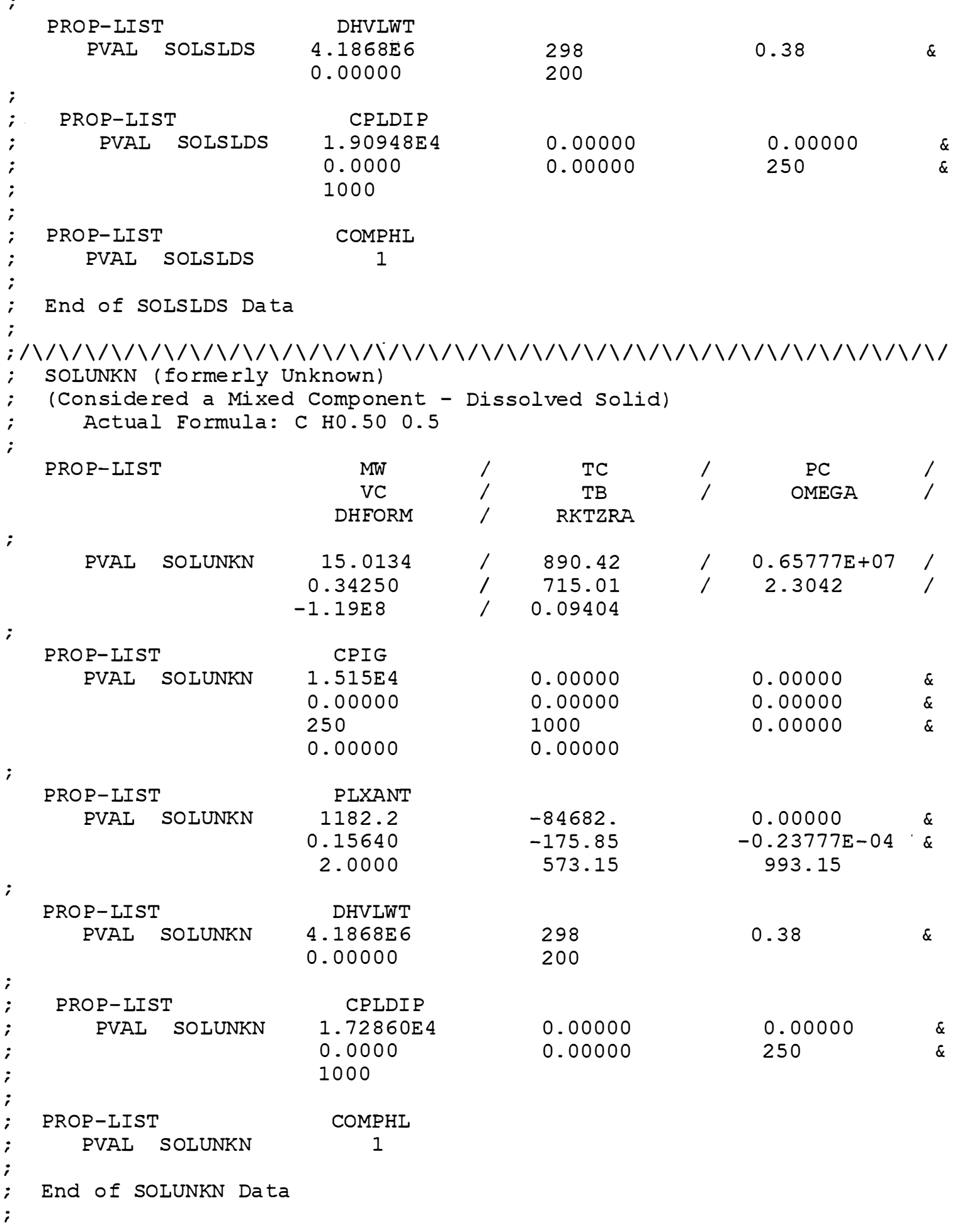


APPENDIX C

\begin{tabular}{|c|c|c|c|c|c|c|c|c|c|c|c|c|c|c|c|c|c|}
\hline \multirow{4}{*}{ Compound } & \multirow{4}{*}{$\begin{array}{l}\text { Primary } \\
\text { Phase }\end{array}$} & \multirow{4}{*}{$\begin{array}{l}\text { Database } \\
\text { Alias } \\
\end{array}$} & \multirow{2}{*}{\multicolumn{15}{|c|}{$\begin{array}{l}\text { APPENDIX C } \\
\text { Quality of Properties in INHSPCD Databank for ASPEN Plus }\end{array}$}} \\
\hline & & & & & & & & & & & & & & & & & \\
\hline & & & \multicolumn{8}{|c|}{ Single Point Values } & \multicolumn{7}{|c|}{ Temperature Correlations } \\
\hline & & & $\overline{M W}$ & TC & $\overline{P C}$ & $\mathrm{VC}$ & OMEGA & DHFORM & $\overline{\text { DGFORM }}$ & DHSFRM & RKTZRA & PLXANT & DHVLWT & CPIG & CPLDIP & CPSPO1* & VSPOLY* \\
\hline Glucose & $\overline{V L}$ & $\mathrm{C} 6 \mathrm{H} 12 \mathrm{O} 6$ & 7 & 5 & 5 & 5 & 5 & 6 & 9 & & 8 & 5 & 0 & 6 & 9 & & \\
\hline Cellulose & $\bar{s}$ & C6H10O5 & 7 & & & & & & & 6 & & & & & & 9 & 3 \\
\hline Xylan & $\bar{s}$ & $\mathrm{C} 5 \mathrm{H} 8 \mathrm{O} 4$ & 7 & & & & & & & 2 & & & & & & 3 & $\overline{3}$ \\
\hline Lignin & $s$ & CXHXOX & 7 & & & & & & & 6 & & & & & & 9 & 3 \\
\hline$\overline{\text { Zymo }}$ & $\bar{s}$ & CHXOXNX & 7 & & & & & & & 4 & & & & & & 4 & 3 \\
\hline Solunkn & $\overline{V L}$ & CXHOX & 7 & 1 & 1 & 1 & 1 & 4 & & & 0 & 1 & 0 & 1 & 3 & & \\
\hline Solsids & $\overline{V L}$ & CHXOXSX & 7 & 1 & 1 & 1 & 1 & 4 & & & 0 & 1 & 0 & 1 & 3 & & \\
\hline Gypsum & $\bar{s}$ & CASO4-2H2O & 7 & & & & & & & 9 & & & & & & 2 & 9 \\
\hline
\end{tabular}

*Solid Properties

Source Codes for Data

9 - Literature Data

8 - Regressed to Literature Data

7 - Calculated Directly (e.g. MW)

6 - Calculated from other Literature Data (e.g. delHf from delHc)

5 - Estimated using PREDICT (C)

4 - Estimated, but not from PREDICT (C)

3 - Used Literature Data for a Similar Compound on Mass Basis

2 - Used Literature Data for a Similar Compound on Molar Basis

1 - Copied from a "Similar" Compound

0 - Unknown Origin 


\begin{tabular}{|c|c|c|c|c|c|c|c|c|c|c|c|c|c|}
\hline \multicolumn{14}{|c|}{$\begin{array}{c}\text { Appendix D } \\
\text { Values in ASPEN Plus INHSPCD (NREL Biofuels) Databank }\end{array}$} \\
\hline Property & $\mid \begin{array}{l}\text { Aspen } \\
\text { Property }\end{array}$ & Units & Glucose| & Xylose & Cellulose & Xylan & Lignin| & Cellulase | & Zymol & Biomass & Solsids & Solunkn & Gypsum \\
\hline Molecular Weight & IMW & & $|180.16|$ & 150.132 & $\begin{array}{ll}162.1436 \\
\end{array}$ & $132.117 \mid$ & $122.493 \mid$ & 22.8398 & $24.6264 \mid$ & 23.238 & 16.5844 & 15.0134 & 172.168 \\
\hline Critical Temperature & ITC & $\mathrm{IK}$ & 1011.1| & 890.42 & & & & & 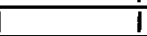 & & 1011.1 & 890.42 & \\
\hline Critical Pressure & IPC & Pascal & $6,200,000 \mid$ & $6,577,700 \mid$ & & & & & & & $6,200,000 \mid$ & $6,577,700$ & \\
\hline Critical Volume & IVC & |cum/Kmole & 0.4165 & 0.3425 & & & & & & & $0.4165 \mid$ & 0.3425 & \\
\hline Acentric Factor & OMMEGA & & $2.5674 \mid$ & 2.3042 & & & & & & & $2.5674 \mid$ & 2.3042 & \\
\hline 1.G. Heal of Formation & IDHFORM & IJ/Kmole & $-1,256,903,000 \mid$ & $-1,040,020,000$ & & & & & i & & $.47,540,000 \mid$ & $-119,000,000$ & \\
\hline 1.G. Free Energy of Form. & DGFORM & IJ/Kmole & $-909,330,000 \mid$ & & & & & & & & i & & \\
\hline Solid Heal of Formation & DDHSFRM & $\mathrm{J} / \mathrm{Kmole}$ & & & $-976,362,000$ & $-762,416,000 \mid$ & $-1,592,659,000$ & $.74,944,000$ & $-130,500,000$ & $-97,133,800$ & & & $-2,022,628,000$ \\
\hline Solid Free Energy of Form. & DDGSFRM & |J/Kmole & 1 & & & & & & & & T & & $\mid-1,797,197,000$ \\
\hline \multirow[t]{9}{*}{ Vapor Pressure } & |PLXANT/1 & |Pascal & 1182.2 & 481.33 & & & & & & & $1182.2 !$ & 1182.2 & \\
\hline & |PLXANT/2 & & -846821 & $-46623 \mid$ & & & & & & & -84682 & -84682 & \\
\hline & IPLXANT/3 & & 0 & 이 & & & & & I & & 이 & 0 & \\
\hline & PPLXNT/4 & & $0.1564 \mid$ & $2.10 \mathrm{E}-02$ & & & & & 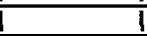 & & $0.1564 \mid$ & 0.1564 & \\
\hline & IPLXANT/5 & & $-175.85 \mid$ & $64.331 \mid$ & & & & & & & $-175.85 \mid$ & -175.85 & \\
\hline & |PLXANT/6 & & $-2.37770 \mathrm{E}-05 \mid$ & $6.22430 \mathrm{E}-06 \mathrm{j}$ & & & & & & & $|-2.37770 E-05|$ & $-2.37770 \mathrm{E}-05$ & \\
\hline & IPLXANT/7 & & 21 & $2 !$ & & & & & 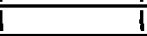 & & $2 \mid$ & 2 & \\
\hline & PLXANT/8 & & $573.15 \mid$ & 573.15 | & & & & & 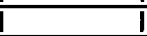 & & 573.15| & 573.15 & \\
\hline & PLXANT/9 & & $993.15 \mid$ & 873.15 & & & & & 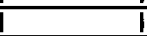 & & $993.15 \mid$ & 993.15 & \\
\hline \multirow[t]{5}{*}{ Heat of Vaporization } & DHVLWT/1 & $\mathrm{J} / \mathrm{Kmole}$ & $502,000 \mid$ & $4,186,800 \mid$ & & & & & 5 & & $4,186,800 \mid$ & $4,186,800$ & \\
\hline & DHVLWT/2 & & 298 & 298 & & & & & i & & $298 \mid$ & 298 & \\
\hline & DHVLWT/3 & & $0.38 \mid$ & 0.38 & & & & & 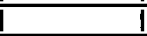 & & $0.38 \mid$ & 0.38 & \\
\hline & DHVLWT/4 & & 이 & 0 & & I & $\frac{1}{1}$ & $\frac{1}{1}$ & 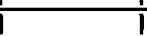 & & 01 & 0 & \\
\hline & DHVLWT/5 & & 200 & $200 \mid$ & & i & & & 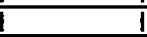 & I & 200 & 200 & \\
\hline Liquid Molar Volume & $\begin{array}{l}\text { RKTZRA } \\
\end{array}$ & |cum/Kmole & $0.35852 \mid$ & $0.29936 \mid$ & & & & & & & $0.09908 \mid$ & 0.09404 & \\
\hline \multirow[t]{7}{*}{ Solid Molar Volume } & VSPOLY/1 & |cum/Kmole & & 1 & 0.106 & $0.0864 \mid$ & $0.0817 \mid$ & $0.0152 !$ & 0.0164 & 0.01549 & & & 0.07469 \\
\hline & VSPOLYI2 & & & i & 0 & 이 & 이 & 이 & 이 & 이 & & & 0 \\
\hline & VSPOLY/3 & & & I & 0 & 이 & 이 & 이 & 이 & 이 & & & 이 \\
\hline & VSPOLYI4 & & & 1 & 0 & 이 & 이 & 이 & 이 & 이 & & & 01 \\
\hline & VSPOLYI5 & & & 1 & 0 & 0 & 이 & 01 & 이 & 이 & & & 0 \\
\hline & VSPOLYI6 & & & 1 & 298.15 & 298.15 & $298.15 \mid$ & $298.15 \mid$ & 298.15 & $298.15 \mid$ & I & & 298.15 \\
\hline & VSPOLYR & & & i & 1000 & $1000 \mid$ & 1000 & 10001 & $1000 \mid$ & $1000 \mid$ & i & & 1000 \\
\hline \multirow[t]{11}{*}{\begin{tabular}{|l} 
1.G. Heal Capacity \\
\end{tabular}} & |CPIG/1 & J J/Kmole K & 207,000 & $170,000 \mid$ & & $i$ & & 1 & i & & 16,900 & 15,150 & \\
\hline & |CPIG/2 & & 이 & 01 & & & & & 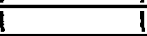 & & 이 & 0 & \\
\hline & |CPIG/3 & & 이 & $0 \mid$ & & & & & & & 이 & 0 & \\
\hline & |CPIG/4 & & 이 & 이 & & & & 1 & & & 이 & 0 & \\
\hline & |CPIG/5 & & 01 & 이 & & & & 1 & I & & 01 & 0 & \\
\hline & |CPIG/6 & & 이 & 어 & & & & & I & & 이 & 0 & \\
\hline & |CPIG & $i$ & 250 & $250 \mid$ & & & & i & i & I & $250 \mid$ & 250 & \\
\hline & |CPIG/8 & & $1000 \mid$ & $1000 \mid$ & & & & & I & & $1000 \mid$ & 1000 & \\
\hline & ICPIG/9 & 1 & 이 & 이 & & & & 1 & I & I & 이 & 0 & \\
\hline & |CPIG/10 & 1 & 01 & 이 & & & & & i & I & 이 & 0 & \\
\hline & |CPIG/11 & & 이 & 01 & & & & & i & & 이 & 0 & \\
\hline \multirow[t]{8}{*}{ Solid Heat Capacity } & |CPSPO1/1 & J J/Kmole K & & I & $-11704 \mid$ & -9529.9 & 31431.7 & 35533 & 38409 & 35910| & I & & 72,182 \\
\hline & |CPSPO1/2 & & & 1 & $672.07 \mid$ & 547.25 & $\begin{array}{l}394.427 \\
\end{array}$ & 0 & 이 & 이 & I & & 97.343 \\
\hline & |CPSPO1/3 & & & 1 & 이 & 0 & 0 & 0 & 01 & 이 & 1 & & 0 \\
\hline & |CPSPO1/4 & & & 1 & 01 & 0 & 0 & 이 & 이 & 이 & 1 & & $\overline{0}$ \\
\hline & |CPSPO1/5 & & & 1 & 01 & 0 & 0 & 0 & 이 & 이 & I & & $-137,330,000$ \\
\hline & ICPSPO1/6 & & & 1 & 01 & 0 & 0 & 0 & 이 & 이 & $\frac{1}{1}$ & & $0.00 \mathrm{E}+00$ \\
\hline & |CPSPO1/7 & & & 1 & $298.15 \mid$ & 298.15 & $\begin{array}{l} \\
\end{array} 298.15$ & 298.15 & $298.15 \mid$ & 298.15 & & & 298 \\
\hline & |CPSPO1/8 & & & 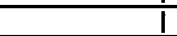 & 1000 & 1000 & 1000 & 1000 & $1000 \mid$ & $1000 \mid$ & - & & 1400 \\
\hline \multirow[t]{7}{*}{ ILiquid Heal Capacity } & |CPLDIP/1 & J J/Kmole K & 207431 & $172857 \mid$ & I & & & & & & $\mid$ & 17286 & \\
\hline & |CPLDIP/2 & & 0 & 이 & i & 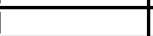 & & & & & 이 & 0 & \\
\hline & |CPLDIP/3 & & 0 & 이 & & & & & & & 이 & 0 & \\
\hline & |CPLDIP/4 & & 0 & 이 & i & 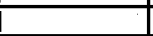 & & & & & 이 & 0 & \\
\hline & |CPLDIP/5 & & 0 & 01 & i & 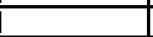 & & & & & 이 & 0 & \\
\hline & |CPLDIP/6 & & 250 & $250 \mid$ & I & 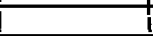 & & & & & $250 \mid$ & 250 & \\
\hline & |CPLDIPI7 & 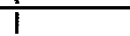 & 1000 & $1000 \mid$ & i & 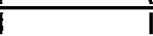 & & & & & $1000 \mid$ & 1000 & \\
\hline
\end{tabular}




\section{APPENDIXE}

Data Values in ASPEN Plus NREL Biofuels INHSPCD Databank

Temperature Correlations Used in ASPEN Plus

Vapor Pressure - PLXANT

$\ln p_{i}^{* \prime}=C_{1 i}+\frac{C_{2 i}}{T+C_{3 i}}+C_{4 i} T+C_{5 i} \ln T+C_{6 i} T^{C_{7 i}}$ for $C_{8 i} \leq T \leq C_{9 i}$

Where,

PLXANT/1....9 correspond to $\mathrm{C}_{1 \mathrm{i} \cdots .9 \mathrm{i}}$

Watson Heat of Vaporization - DHVLWT

$\Delta_{\text {vap }} H_{i}^{*}(T)=\Delta_{\text {vap }} H_{i}^{*}\left(T_{1}\right)\left(\frac{1-T / T_{c i}}{1-T_{1} / T_{c i}}\right)^{a_{i}+b_{i}\left(1-T / T_{c i}\right)}$ for $T>T_{\min }$

Where,

$\Delta_{\text {vap }} H_{i}^{*}\left(T_{1}\right)=$ Heat of Vaporization at temperature $T_{1}$

Parameter Symbol

TC $\quad \mathrm{T}_{\mathrm{ci}}$

DHVLWT/1 $\Delta_{\text {vap }} H_{i}^{*}\left(T_{1}\right)$

DHVLWT/2 $\quad T_{1}$

DHVLWT/3 $\quad a_{i}$

DHVLWT/4 $\quad b_{i}$

DHVLWT/5 $\quad T_{\min }$

Rackett Liquid Molar Volume - RKTZRA

$V_{m}^{\prime}=\frac{R T_{c}\left(Z_{m}^{R A}\right)^{\left[1+\left(1-T_{r}\right)^{2 / 7}\right]}}{P_{c}}$

Where,

$T c=\sum_{i} \sum_{j} \dot{x}_{i} x_{j} V_{c i} V_{c j}\left(T_{c i} T_{c j}\right)^{1 / 2}\left(1-k_{i j}\right) / V_{c m}^{2}$

$\frac{T_{c}}{p_{c}}=\sum_{i} x_{i} \frac{T_{c i}}{p_{c i}}$

$Z_{m}^{R A}=\sum_{i} x_{i} Z_{i}^{*} R A$

$v_{c m}=\sum_{i} x_{i} v_{c i}$

$T_{r}=\frac{T}{T_{c}}$ 
Rackett Liquid Molar Volume - RKTZRA - Continued

$\begin{array}{ll}\text { Parameter } & \text { Symbol } \\ \text { TC } & \mathrm{T}_{c i} \\ \text { PC } & \mathrm{p}_{c i} \\ \text { VC } & \mathrm{V}_{c i} \\ \text { RKTZRA } & \mathrm{Z}_{\mathrm{i}}^{\text {RA }} \\ \text { RKTKIJ } & \mathrm{k}_{\mathrm{ij}}\end{array}$

Solids Volume Polynomial - VSPOLY

$V_{i}^{*}{ }^{*}(T)=C_{1 i}+C_{2 i} T+C_{3 i} T^{2}+C_{4 i} T^{3}+C_{5 i} T^{4}$ for $C_{6 i} \leq T \leq C_{7 i}$

Where,

VSPOLY/1....7 correspond to $\mathrm{C}_{1 \mathrm{i}} \ldots .7 \mathrm{i}$

Ideal Gas Heat Capacity - CPIG

$$
\begin{aligned}
& C_{p}^{* i g}(T)=C_{1 i}+C_{2 i} T+C_{3 i} T^{2}+C_{4 i} T^{3}+C_{5 i} T^{4}+C_{6 i} T^{5} \text { for } C_{7 i} \leq T \leq C_{8 i} \\
& C_{p}^{* i g}(T)=C_{9 i}+C_{10 i} T \text { for } T<C_{7 i}
\end{aligned}
$$

Where,

CPIG/1...11 correspond to $C_{1 \mathrm{i} \cdots 11 \mathrm{i}}$

\section{Solids Heat Capacity}

$C_{p, i}^{*, s}(T)=C_{1 i}+C_{2 i} T+C_{3 i} T^{2}+\frac{C_{4 i}}{T}+\frac{C_{5 i}}{T^{2}}+\frac{C_{6 i}}{\sqrt{T}}$ for $C_{7 i} \leq T \leq C_{8 i}$

Where,

CPSP01/1...8 correspond to $\mathrm{C}_{1 \mathrm{i} \ldots 8 \mathrm{i}}$

DIPPR Liquid Heat Capacity - CPLDIP

$C_{p, i}^{*}(T)=C_{1 i}+C_{2 i} T+C_{3 i} T^{2}+C_{4 i} T^{3}+C_{5 i} T^{4}$ for $C_{6 i} \leq T \leq C_{7 i}$

Where,

CPLDIP/1 $\ldots . .7$ correspond to $\mathrm{C}_{1 \mathrm{i} \ldots 7 \mathrm{i}}$ 


\section{APPENDIX F \\ ASPEN Plus Physical Property Route Modifications to Enable the DIPPR Liquid Heat Capacity Correlation}

The standard physical property calculation route in ASPEN PLUS does not use a correlation for liquid heat capacity; rather, it uses correlations for the ideal gas heat capacity and the heat of vaporization. For some compounds studied here, which exist in the liquid phase, a liquid heat capacity rather than a heat of vaporization or gas heat capacity was available. To take advantage of these data, the DIPPR correlation for liquid heat capacity (available in ASPEN PLUS) was used. To enable this model, a modification to the physical property route was necessary. This modification is:

\section{PROP-REPLACE NRTL NRTL}

PROP DHL DHL09

These imput language statements (also available in Model Manager) modify the basic physical property option set, NRTL, to use the DIPPR liquid heat capacity route, DHL09, for the calculation of liquid enthalpy, DHL09.

With this modification, the DIPPR liquid heat capacity model will be used only if data are present. If no data are present for this model (CPLDIP), the calculations will revert to the standard methods of using the IG heat capacity and heat of vaporization.

This method has a bug in it that Aspen Technology is not willing to fix at this time. Therefore, even though this was a good method for calculating the necessary liquid heat capacity. it was not available as of this writing. 


\section{REPORT DOCUMENTATION PAGE}

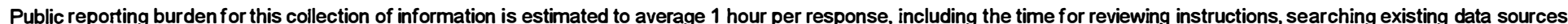

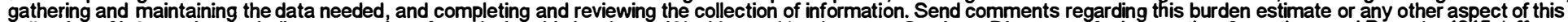

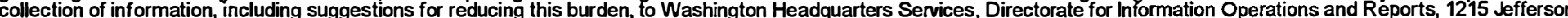

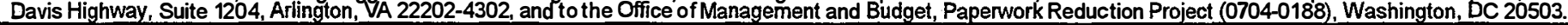
1. AGENCY USE ONLY (Leave blank) 2. REPORT DATE
April 1996
3. REPORT TYPE AND DATES COVERED
NREL Report

4. TITLE AND SUBTITLE

Development of a Biofuels Physical Property Database for ASPEN+ Simulators

5. FUNDING NUMBERS

BF521004

\section{AUTHOR(S)}

R.J. Wooley, V. Putsche

\section{PERFORMING ORGANIZATION NAME(S) AND ADDRESS(ES)}

National Renewable Energy Laboratory

1617 Cole Boulevard

Golden, CO 80401

9. SPONSORING/MONITORING AGENCY NAME(S) AND ADDRESS(ES)

National Renewable Energy Laboratory

1617 Cole Boulevard

Golden, CO 80401-3393

\section{SUPPLEMENTARY NOTES}

\section{2a. DISTRIBUTION/AVAILABILITY STATEMENT}

National Technical Information Service

U.S. Department of Commerce

5285 Port Royal Road

Springfield, VA 22161 12b. DISTRIBUTION CODE

UC-1503

\section{ABSTRACT (Maximum 200 words)}

Physical property data for many key components used to simulate ethanol from biomass are not available in the standard ASPEN PLUS property databases. Therefore, we must evaluate the literature, estimate properties, and determine a set of consistent physical properties for all components of interest. The components must then be entered into a in-house NREL ASPEN PLUS database so they can be called on without being retyped into each specific simulation.

\begin{tabular}{|c|c|c|c|}
\hline \multirow{2}{*}{\multicolumn{3}{|c|}{$\begin{array}{l}\text { 14. SUBJECT TERMS } \\
\text { simulator, physical properties, vapor pressure, heat of vaporization, liquid density }\end{array}$}} & \multirow{2}{*}{$\frac{\text { 15. NUMBER OF PAGES }}{\text { 16. PRICE CODE }}$} \\
\hline & & & \\
\hline $\begin{array}{l}\text { 17. SECURITY CLASSIFICATION } \\
\text { OF REPORT }\end{array}$ & $\begin{array}{l}\text { 18. SECURITY CLASSIFICATION } \\
\text { OF THIS PAGE }\end{array}$ & $\begin{array}{l}\text { 19. SECURITY CLASSIFICATION } \\
\text { OF ABSTRACT }\end{array}$ & 20. LIMITATION OF ABSTRACT \\
\hline
\end{tabular}

